\title{
Source rock characteristics and hydrocarbon generation potential in Brunei-Muara district, Brunei Darussalam: a comparative case study from selected Miocene-Quaternary formations
}

\author{
Liyana Nadiah Osli ${ }^{1} \cdot$ Mohamed Ragab Shalaby ${ }^{1,2} \cdot$ Md. Aminul Islam $^{1}$
}

Received: 15 December 2020 / Accepted: 8 March 2021 / Published online: 20 March 2021

(c) The Author(s) 2021

\begin{abstract}
A comparative analysis on source rock properties has been carried out on the Miocene-Pliocene formations as well as the Quaternary terrace deposits using Rock-Eval pyrolysis results and organic petrography as well as some biomarkers results. Samples were obtained from outcrops of the Quaternary terrace deposits, Pliocene-aged Liang Formation together with the Miocene Miri and Setap Shale formations in Brunei-Muara district, with sample lithologies ranging from coal, coaly shale, shale and lignitic sand. High total organic carbon (TOC) and $S_{2}$ values ranging from 41.8 to $62.4 \%$ and $7.40 \mathrm{mg} \mathrm{HC} / \mathrm{g}$ rock to $122 \mathrm{mg} \mathrm{HC} / \mathrm{g}$ rock, respectively, are identified in coals of the terrace deposit, Liang and Miri formations, making these as the best potential source rock due to the "good to excellent" generating potential. Meanwhile, a "fair to poor" potential is exhibited for the coaly shale, shale and lignitic sand samples as a result of their low TOC, HI and $S_{2}$ values. The organic matter is composed of kerogen type III (gas prone) and type II-III (mixed oil and gas prone). Organic matter in all studied formations originate from a terrestrial-source, as proven by the abundance of huminite. Organic petrographical and biomarkers studies suggest that the coals and lignitic sand samples were deposited in a mangrove-type mire in a lower delta setting, under oxic and limnic to limnotelmatic conditions, except sample DD2-1, which is deposited in a less water-saturated environment. The samples display the presence of bi-modal and normal distribution of $n$-alkanes. For all of the samples, the dominating plant types in the palaeomire are of soft, herbaceous plants and this is supported by the low vegetation index and moderate $P_{\text {aq }}$ values. All the studied samples are thermally immature to early mature, as exhibited by the $T_{\max }$ values that range from 300 to $437{ }^{\circ} \mathrm{C}$ and vitrinite reflectance readings of $0.22 \%$ to $0.46 \%$.
\end{abstract}

Keywords Miri formation - Setap Shale formation - Liang formation - Quaternary terrace deposits · Source rock characterization $\cdot$ Organic petrography $\cdot$ Coal rank

\section{Introduction}

In Brunei Darussalam, good-quality source rocks exist only as centimeter-thick layers and lenses, without having a mappable thickness and lateral distribution (Scherer and Hitam 1992). These organic-rich layers are present in the Neogene sediments of Brunei, which are regularly studied on varying

Liyana Nadiah Osli

anadiah.osli@gmail.com

1 Department of Geosciences, Universiti Brunei Darussalam, Jalan Tungku Link, Bandar Seri Begawan BE 1410, Negara Brunei Darussalam

2 Geology Department, Faculty of Science, Tanta University, Tanta 31527, Egypt subject matters; most are associated with petroleum geology (James 1984; Levell 1987; Sandal 1996; Schreurs 1997; Petronas 1999; Lambiase and Cullen 2013), regional tectonics (Tingay et al. 2003, 2009), sedimentology (Lambiase et al. 2002; Siddiqui et al. 2013; Back et al. 2008; Lambiase and Cullen 2013; Rahman et al. 2014) and palaeodepositional environment studies (Back et al. 2001; Torres et al. 2011).

The Belait Formation has continuously become the primary formation of focus for source rock characterization studies in Brunei Darussalam, such as those carried out by Abdullah (1999; 2003) and Curiale et al. (2000). The Belait Formation of the Champion Delta complex accommodates organic-rich sediments in the form of either in-situ coal seams or marine sediments with dispersed organic matter (Schreurs 1997). Similar coal-bearing sediments are also identified in other formations other than the Belait 

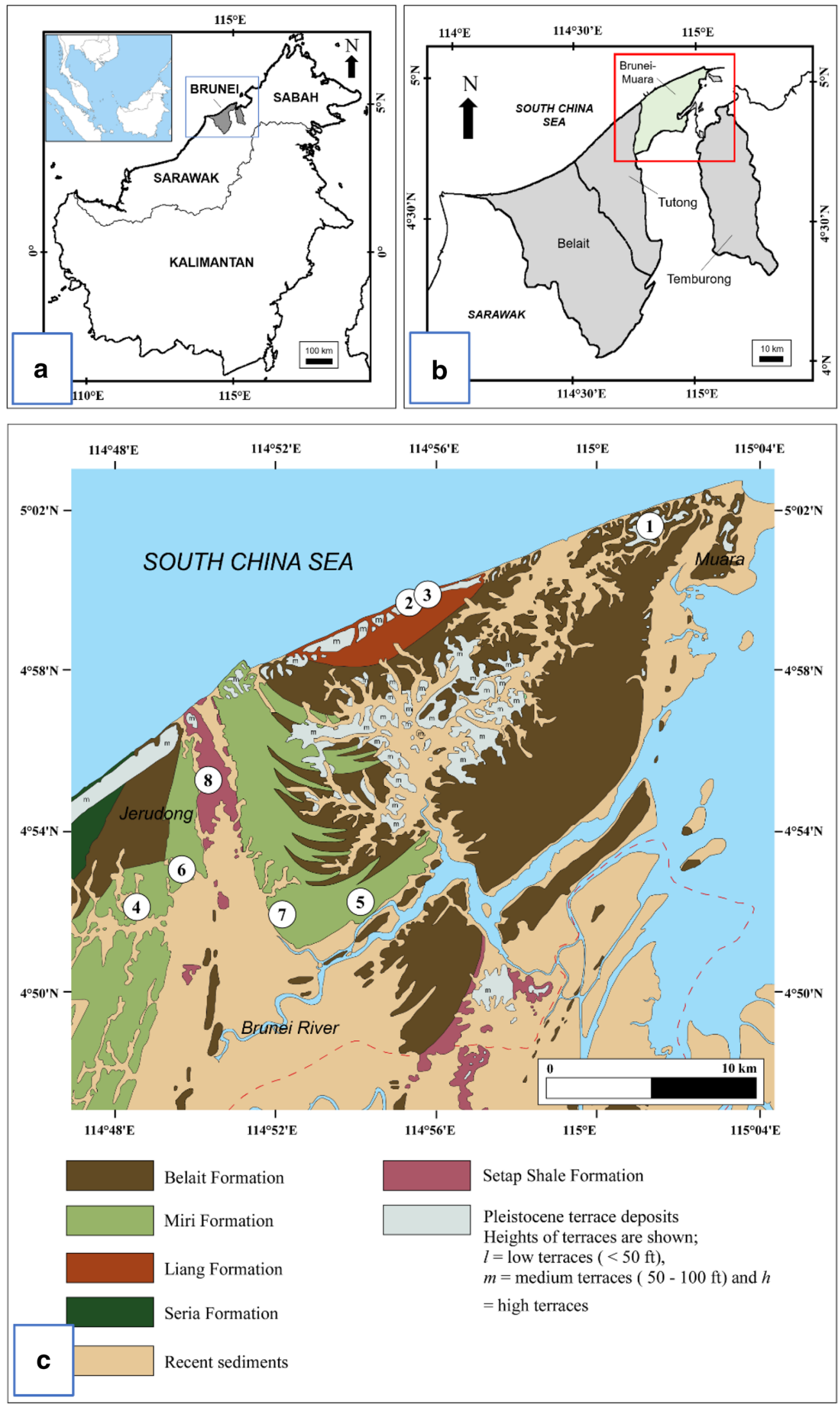
४Fig. 1 Location map showing; a The position of Brunei Darussalam within Borneo; b The study area (Brunei-Muara district) highlighted in light green; c Distribution of different formations encountered in the Brunei-Muara district, including the sites of sample collection. Modified after (Wilford 1961)

Formation in Brunei Darussalam. In the Brunei-Muara district, coals are identified in the Miri and Liang formations, as well as in terrace deposits. The Miri Formation is lithologically similar with the Belait Formation and both of them are synchronous with each other, together with the Seria and Setap Shale formations (Figs. 1 and 2; Wilford 1961).

Younger deposits occur as terraces, which are deposited within the last million years, covering an area of approximately $2400 \mathrm{sq} \mathrm{km}$ in Brunei (Tate 1971). Wood particles are present within the terrace deposits, which can somehow be comparable with the lignites present in the other formations. The MR1 outcrop occurring along the Muara-Tutong highway is an exposure of Quaternary terrace deposits separated from the underlying layers of sand and shale belonging to the Belait Formation by an angular unconformity (Fig. 3a and $b)$. A closer examination of the terrace deposit indicates the presence of brown-coloured carbonaceous (Fig. 3c) sand with high-angle cross-bedding (Fig. 3d) and occasional pebble layers as well as lignified wood.

To date, there has been no published source rock studies concerning the Miri, Liang and Setap Shale formations of Brunei Darussalam. Most of the available studies that focus on one or some of the aforementioned formations primarily concerns the formations' potential as a petroleum reservoir. Studies on the geology of terrace deposits in Brunei are also limited but there are multiple studies carried out on these formations in neighboring regions. The organic geochemistry and depositional environment of the Liang Formation in Sarawak, Malaysia has been analyzed by Hakimi et al. (2013) and Murtaza et al. (2018), respectively. The Miri Formation in Sarawak has been widely assessed for its reservoir potential (Abieda et al. 2005; Jia and Rahman 2009; Siddiqui et al. 2014) and depositional facies (Rahman and Tahir 2018). Organic matter maturity and palaeodepositional environment of the Setap Shale Formation of Sabah, Malaysia was investigated by Burgan and Ali (2010) and were comparatively examined with the Belait Formation of the same region. Similar exposures of terrace deposits are also observed in Miri, Sarawak, and these units have been examined by Kessler and Jong (2014). Although Quaternary deposits in Brunei are not typically examined for their petroleum properties, it is still worth examining the lignites and lignitic sands of the terrace, especially relating to their potential as a possible source rock.

The central idea of this research is to evaluate the source rock potential of the terrace deposits, Liang, Miri and Setap Shale formations using outcrop samples in the Brunei-Muara district of Brunei Darussalam (Fig. 1a-c). To do so, the geochemical properties and hydrocarbon generation potential of the three formations are investigated. Our results are based on the integration of data from Rock-Eval pyrolysis, organic petrography and biological markers in order to characterize the potential source rocks.

Geochemical properties examined include organic matter type, coal rank and thermal maturity, whereas palaeoenvironment and the conditions of depositions were mostly identified through organic petrography. Furthermore, the intention of this study is also to provide more information on the Liang, Miri and Setap Shale formations to enhance our understanding about the petroleum system as well as the general stratigraphy of Brunei.

\section{Geological settings}

The geology of Brunei is mainly controlled by delta systems that evolved since Miocene (James 1984; Sandal 1996; Schreurs 1997). The oldest of the three delta complexes is the Meligan delta that was generated in the Palaeogene. Middle to late Miocene deposits belonging to the Champion delta are separated from the Meligan Delta by a significant regional unconformity (Hutchison 2005). Baram Delta is the youngest of the three deltas and occurred from the early Pliocene to recent (Sandal 1996). Formation of these delta systems can be traced back to the geological history of Borneo that was active since the Mesozoic. In the Cenozoic, the clockwise rotation of the Philippine Sea plate led to the plate boundaries changes that are essential in developing the current tectonic pattern observed in Southeast Asia (Hall 1997). Borneo began its anti-clockwise rotation in Neogene, during which there was also a change in sedimentation in basins that surrounded the island. A counter-clockwise rotation of the island of no more than $25^{\circ}$ began approximately $20 \mathrm{Ma}$ (Hall 1996; Moss et al. 1997; Baillie et al. 2004). This is attributed to the northward motion of Australia during that time (Hall 1996) and concurrently happening to this is the anti-clockwise rotation of west Sulawesi and adjacent Sundaland blocks (Hall 1996). Borneo was uplifted as a result of compressional forces in the Neogene (Baillie et al. 2004), causing rapid delta progradation that results in an elevated sediment production. Erosion of central Borneo mountains led to more sediment input into surrounding basins including the Baram basin (Hutchison 1996; Hall and Nichols 2002; Baillie et al. 2004).

Hydrocarbons in Brunei Darussalam are attributed to sediments of the Champion delta, which is represented by the Setap, Belait, Lambir, Miri and Seria formations (Fig. 2; James 1984; Koopman 1996; Sandal 1996; Curiale et al. 2000). The argillaceous Setap Shale Formation is overlain by the Belait, Miri, Seria and Lambir Formations (Tate

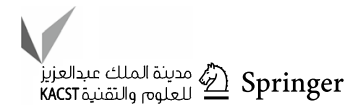




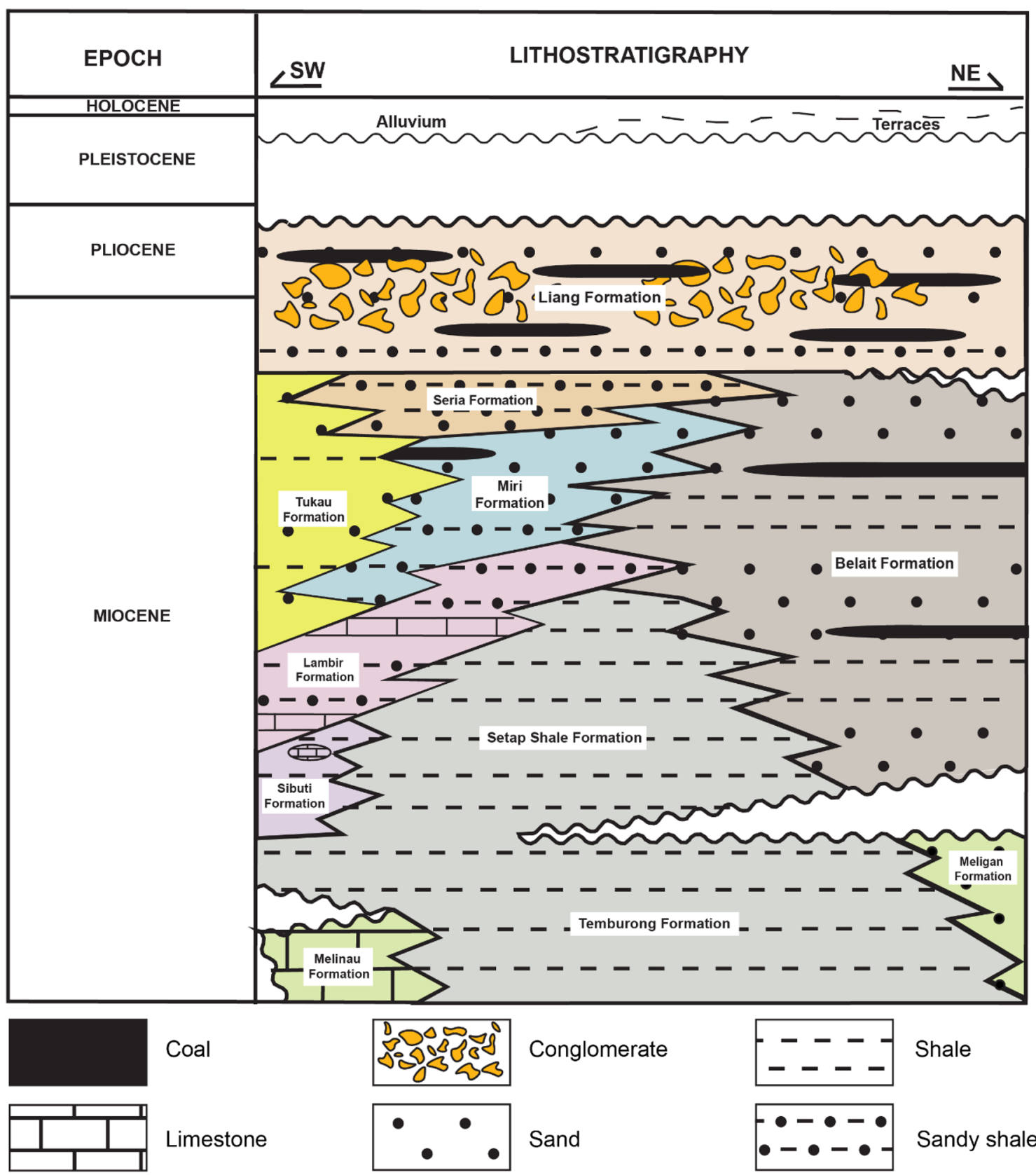

Fig. 2 Chronostratigraphy of onshore Brunei Darussalam (modified after Sandal 1996)

1974). The Belait Formation is synchronous with the Setap Shale Formation (early to Middle Miocene) and the Lambir, Miri and Seria formations (middle to Late Miocene). Environment of deposition differs between the formations, as observed from outcrops across the study area. The Belait Formation is composed of primarily sandstone with shales and coal interbeds. The Miri Formation is lithologically similar with the Belait Formation, comprising of mainly arenaceous sediments with subordinate clays and shales (Wilford 1961), although it is relatively more marine as it was deposited in a shallow marine environment. The Setap Shale was deposited in a deep marine environment that occurred in the Oligocene, comprising of clay and shale with thin silty and sandy beds (Wilford 1961; Back et al. 2001). The Liang Formation consists of two members; the Berakas Member is located within the Berakas Syncline whereas the Lumut Member is located in the Lumut Hills (Wilford 1961). The main lithologies of this formation are sand, clay and gravel with lignite beds. 


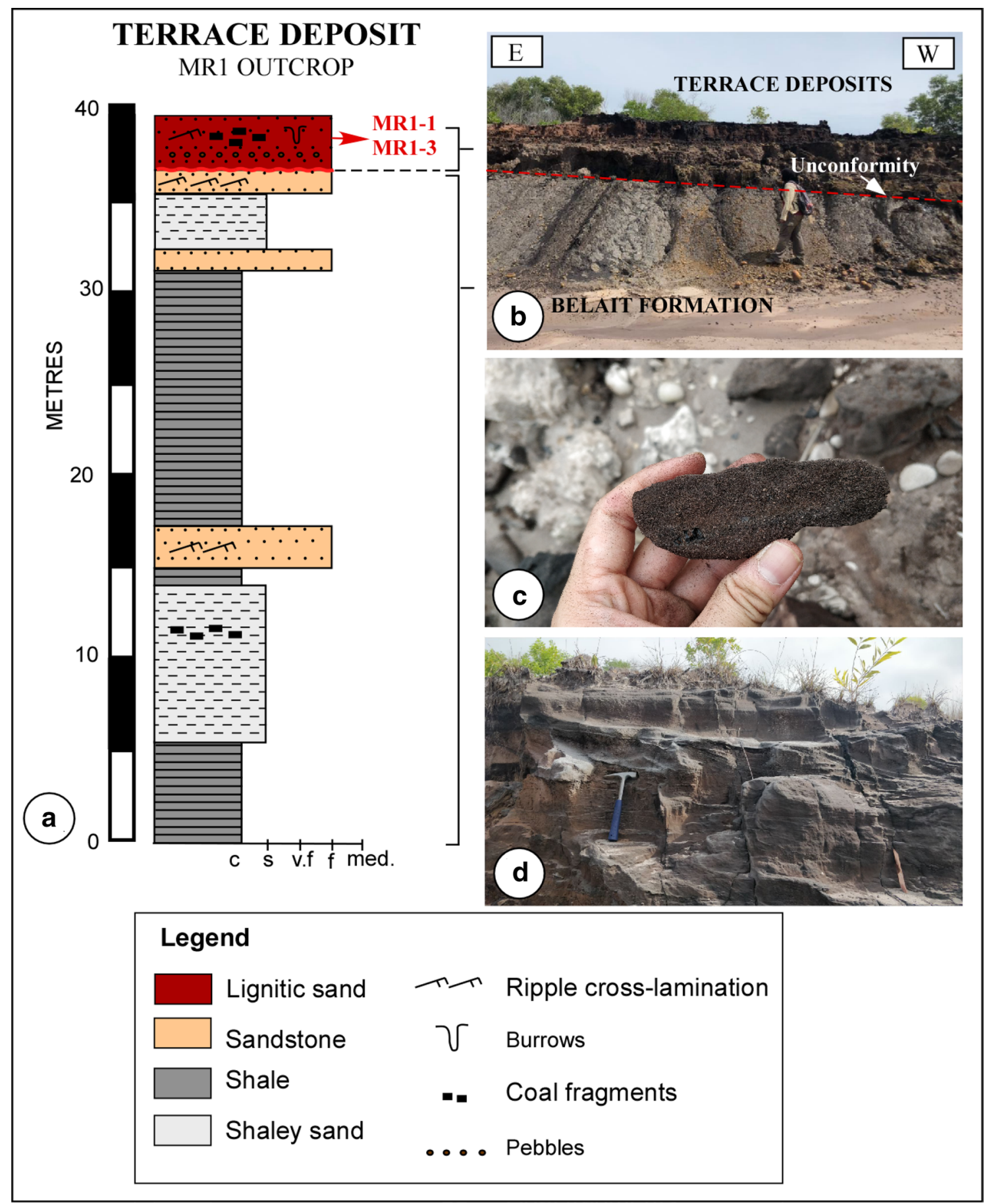

Fig. 3 a A representative lithostratigraphic column of the terrace deposit samples as observed in the MR1 outcrop; b An unconformity separating the younger terrace deposit and older Belait Formation; c

\section{Methodology}

\section{Field work and sampling}

A total of 16 samples derived from the Quaternary terrace, Miri, Setap Shale and the Berakas Member of Liang
Lignitic sand of the terrace deposit containing coal clasts, from which samples MR1-1 and MR1-3 were derived in the outcrop; d Highangle cross-laminations are predominant in the terrace deposits

Formations were collected from 8 different locations across the Brunei-Muara district are assessed in this study (Fig. 1). Lithology of samples collected range from coals, coaly shale, lignitic sand and shale. In Table 2, sample ID and corresponding lithology are summarized. All coal samples of this study are in-situ except MR1-1, LU1-1 and TL1-1 
samples. Outcrops were selected based on information derived from literature, reference from previous field trips, minimal disturbance and outcrop accessibility. Prior to sampling, sedimentological structures are recorded.

\section{Analytical procedures}

All 16 samples collected from the terrace deposits, Liang, Miri and Setap Shale formations were analyzed to obtain Rock-Eval data in Hydrocarbons Chemistry and Technology Lab, Technical University of Crete. Following this, representative samples from each formation were selected for subsequent analyses in this study. For organic petrography and vitrinite reflectance, a total of 8 samples were examined in the Department of Geology, University of Patras, Greece. Biomarkers analyses were carried out in Hydrocarbons Chemistry and Technology Lab, Technical University of Crete, in which 5 samples were chosen for rock extraction and fractionation, whereas 3 samples were selected for gas chromatography (Table 1).

In Rock-Eval pyrolysis, samples are initially crushed, sieved and dried overnight at $40^{\circ} \mathrm{C}$. Rock samples were then purged with nitrogen gas and heated at $300^{\circ} \mathrm{C}$ for $6 \mathrm{~min}$. The samples were subsequently pyrolyzed to $650^{\circ} \mathrm{C}$ and further burnt in the oxidation oven in air. Principal pyrolysis parameters such as $S_{1}$ (a measure of free hydrocarbons or bitumen available in the source rock before pyrolysis; $\mathrm{mg} \mathrm{HC/gm}$ rock), $S_{2}$ (a measure of the potential hydrocarbon volume formed during thermal pyrolysis; $\mathrm{mgHC} / \mathrm{gm}$ rock), $\mathrm{S}_{3}$ (a measure of inorganic-originated $\mathrm{CO}_{2} ; \mathrm{mg} \mathrm{CO} 2 / \mathrm{gm}$ rock),
$T_{\max }$ (temperature with the maximum amount of hydrocarbon generated during pyrolysis) and TOC (total organic content) were obtained from the Rocksix V4.08 software.

Primary parameters obtained from Rock-Eval pyrolysis can be integrated in different ways to analyze several properties of a potential source rock. PI is defined as the amount of free hydrocarbon generated to the total amount of hydrocarbon that the organic matter is capable of generating (Tissot and Welte 1984; Peters and Cassa 1994). This parameter is calculated through the formula $\left(\mathrm{PI}=\mathrm{S}_{1} / \mathrm{PY}\right)$, whereas Production Yield (PY) is generated from the sum of $\mathrm{S} 1$ and $\mathrm{S} 2$ $\left(\mathrm{PY}=\mathrm{S}_{1}+\mathrm{S}_{2}\right)$. Two parameters that are useful in determining the kerogen types present in a source rock are Hydrogen Index (HI) and Oxygen Index (OI), in which both parameters are calculated using the formulae $\left(\mathrm{HI}=\mathrm{S}_{2} / \mathrm{TOC} \times 100\right)$ and $\left(\mathrm{OI}=\mathrm{S}_{3} / \mathrm{TOC} \times 100\right)$ respectively.

Selected samples that were initially crushed to appropriate sizes $(<1 \mathrm{~mm})$ or block samples were polished and prepared according to ISO 7404-2 (2009) for maceral analysis. Examination of samples were carried out using a LEICA DMRX microscope at the Department of Geology, University of Patras. Maceral identification was performed in oil immersion under both white incident light and blue-light excitation (ISO 7404-3 2009; ASTM D7708 2014), following the nomenclature of the Stopes-Heerlen System as modified by ICCP System 1994 (ICCP 1998; 2001; Sýkorová et al. 2005; Pickel et al. 2017). Relative abundance of macerals was determined using point-count analyses (500 points).

Mineral matter input in rocks is represented as the ash content of the samples (Diessel 1992). Ash yields were identified

Table 1 List of samples used in all analyses of this study

\begin{tabular}{|c|c|c|c|c|c|c|c|}
\hline $\begin{array}{c}\text { Formation } \\
\text { name }\end{array}$ & $\begin{array}{l}\text { Sample } \\
\text { ID }\end{array}$ & $\begin{array}{l}\text { Geochemical } \\
\text { analysis }\end{array}$ & $\begin{array}{c}\text { Maceral } \\
\text { abundance }\end{array}$ & $\begin{array}{l}\text { Vitrinite } \\
\text { reflectance }\end{array}$ & $\begin{array}{c}\text { Ash } \\
\text { content }\end{array}$ & $\begin{array}{c}\text { Rock } \\
\text { extraction } \\
\text { and } \\
\text { fractionation }\end{array}$ & $\begin{array}{c}\text { GC-MS } \\
\text { Chromato } \\
\text { graphy }\end{array}$ \\
\hline \multirow{3}{*}{$\begin{array}{l}\text { Terrace } \\
\text { deposit }\end{array}$} & MR1-1 & & & & & & \\
\hline & MR1-2 & & & & & & \\
\hline & MR1-3 & & & & & & \\
\hline \multirow{6}{*}{$\begin{array}{l}\text { Liang } \\
\text { formation }\end{array}$} & BR1-1 & & & & & & \\
\hline & BR2-1 & & & & & & \\
\hline & BR2-2 & & & & & & \\
\hline & BR2-3 & & & & & & \\
\hline & BR2-5 & & & & & & \\
\hline & BR2-6 & & & & & & \\
\hline \multirow{4}{*}{$\begin{array}{c}\text { Miri } \\
\text { formation }\end{array}$} & LU1-1 & & & & & & \\
\hline & TL1-1 & & & & & & \\
\hline & TN1-1 & & & & & & \\
\hline & DD2-1 & & & & & & \\
\hline \multirow{3}{*}{$\begin{array}{c}\text { Setap } \\
\text { shale } \\
\text { formation }\end{array}$} & JD1-1 & & & & & & \\
\hline & JD1-2 & & & & & & \\
\hline & JD1-3 & & & & & & \\
\hline
\end{tabular}


from proximate analysis that was undertaken according to ASTM D3174 (2004). In identifying ash yields, samples were initially crushed to sizes of less than $200 \mu \mathrm{m}$ and combusted at $750{ }^{\circ} \mathrm{C}$ using a Selecta Muffle furnace. Percentage of ash is determined by weighing the ash left behind post-combustion with respect to the weight of sample [(weight of ash postcombustion/total sample weight before combustion) $\times 100$ ].

In biomarkers analysis, approximately $30 \mathrm{~g}$ of rock from selected samples were initially crushed and sieved using 60 mesh before undergoing solvent extraction using the Soxhlet technique, which utilizes a dichloromethane-methanol mixture (90:10 volume). Copper tips were used during extraction to eliminate presence of elemental sulphur. Excess $n$-pentane were then utilized for de-asphalting of rock extracts and subsequently filtered using Teflon syringe filters $(0.45 \mu \mathrm{m})$. Open-column chromatography was applied to separate the isolated maltene portion into saturates, aromatics and polar (NSO) compound groups. These compounds were then eluted using different solutions; $7 \mathrm{ml}$ of $n$-pentane for saturates, $6.5 \mathrm{ml}$ of toluene for aromatics and a $60: 40 \mathrm{v} / \mathrm{v}$ mixture of toluene-methanol for NSO compounds.

In GC-MS analysis, $n$-hexane $(0.5 \mathrm{ml})$ were used to dissolve the saturated and aromatic fractions, with $15 \mu \mathrm{l}$ of internal standard added. This standard is composed of a Chiron mixture S-4121-ASS-IO containing $n$-C12-D26, 1-Fluoronaphthalene, 3-Fluorophenanthrene, $n$-C16-D34, 2-Fluorochrysene, and $5 \beta(\mathrm{H})$ Cholane. GC-MS analysis was carried out on an Agilent 5975E Mass Spectrometer and an automatic liquid sampler (ALS). The electron impact (EI)-mass spectra were acquired at $70 \mathrm{eV}$ in full scan mode (scan range from $\mathrm{m} / \mathrm{z}=50-850$ ) as well as in Single Ion Monitoring (SIM) on selected ions of interest. Identification of compounds were done using their relative retention times as well as with comparison with mass spectra recorded in literature. Concentration of $n$-alkanes were calculated using the Relative Response Factors (RRF) that was determined by a 5-point calibration, using a quantitative standard mixture that contains $n$-alkane and isoprenoid.

Different biomarker parameters obtained from the analyses and their derivations which include the pristane/phytane ratio, isoprenoid/n-alkanes ratio and the Carbon Preference Index (CPI) can be correlated together for palaeodepositional environment interpretation. The Carbon Preference Index (CPI) is a derivative from biomarkers results that can be referred to in indicating the thermal maturity of samples (Peters et al., 2007b). A thermally immature organic matter is indicated by CPI values that are significantly high or containing values that are less than 1.0 (Peters et al., 2005). $\mathrm{CPI}$ is calculated through the formula:

$$
\begin{aligned}
\mathrm{CPI}=0.5 * & \left\{\frac{\mathrm{C} 25+\mathrm{C} 27+\mathrm{C} 29+\mathrm{C} 31+\mathrm{C} 33}{\mathrm{C} 24+\mathrm{C} 26+\mathrm{C} 28+\mathrm{C} 30+\mathrm{C} 32}\right. \\
& \left.+\frac{\mathrm{C} 25+\mathrm{C} 27+\mathrm{C} 29+\mathrm{C} 31+\mathrm{C} 33}{\mathrm{C} 26+\mathrm{C} 28+\mathrm{C} 30+\mathrm{C} 32+\mathrm{C} 34}\right\}
\end{aligned}
$$

\section{Results}

\section{Lithological features}

Sedimentary structures, field-based lithology and other prominent features as observed on outcrops were recorded before channel sampling was carried out. Sediments with organogenic and organic-rich characteristics were selected for sampling; these vary from coals to carbonacenous rocks and shales. The lithological columns of selected outcrops are constructed to show the sample collection site, lithological variations and sedimentary structures recorded (Figs. 3, 4, and 5).

Preliminary classification of the samples based on lithology can be further improved with the use of ash content of the samples, which is a representative of mineral matter input of the samples (Diessel 1992). The results show that MR1-1 and MR1-3 samples from terrace deposits have ash content of $11.3 \%$ and $90.8 \%$ respectively. In the Liang Formation, coal samples have ash content ranging from 4.74 to $12.2 \%$, with the highest ash content identified in sample BR2-2. A very low ash content of $0.64 \%$ is identified in LU1-1 sample of the Miri Formation. In the Setap Shale Formation, ash content of $92.3 \%$ is detected.

Ash values detected in the samples can be plotted on the classification of coal introduced by ECE-UN (1998) as displayed in Fig. 6. According to the classification, most of the coals from terrace deposits, Liang and Miri formations are characterized as high-grade coals due to the low ash content. On the contrary, the high ash value of more than 90\% has led to samples JD1-3, MR1-3 and DD2-1 being characterized as non-carbonaceous rocks (Fig. 6).

\section{Rock-Eval pyrolysis and geochemical parameters}

The TOC value for the MR1-1 coal sample is $54.8 \%$, while the lignitic sand samples have TOC readings that range from 3.2 to $4.13 \%$. The TOC values for samples of the Liang Formation ranges from 1 to $48.9 \%$, with the highest TOC value recorded in BR2-1 coal sample. All coal samples in the formation display high TOC values that averages to more than $40 \%$, while the coaly shale, lignitic

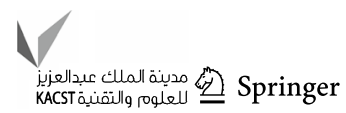


Fig. 4 a A representative lithostratigraphic column of the Liang Formation as observed in the Berakas (BR) outcrop; b and c Locations of the BR outcrop where samples were collected

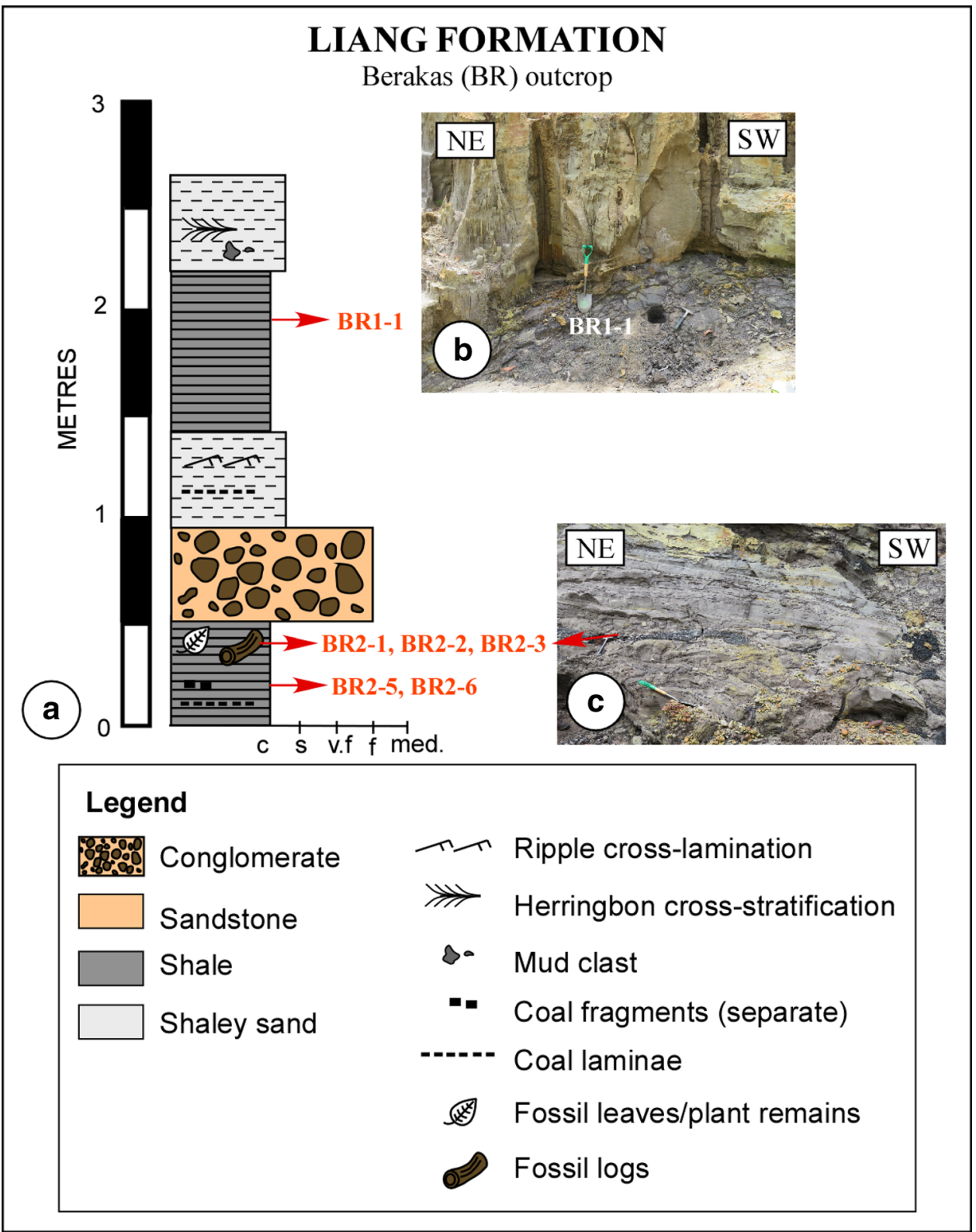

sand and shale samples contain lower TOC readings that range from 1 to $2.65 \%$. The average TOC value for coal samples of the Miri Formation is $59.3 \%$, while the shale samples record readings that range from 0.61 to $1.41 \%$. The Setap Shale Formation contains very low TOC and $\mathrm{S}_{1}$ values ranges from 0.03 to $0.07 \mathrm{mg} \mathrm{HC/g}$ and $\mathrm{S}_{2}$ values ranging between 0.61 and $0.75 \mathrm{mg} \mathrm{HC/g}$ rock.

The $S_{1}$ and $S_{2}$ values for terrace deposits range from 0.04 to $5.81 \mathrm{mg} \mathrm{HC} / \mathrm{g}$ rock and 0.55 to $105.9 \mathrm{mg} \mathrm{HC} / \mathrm{g}$ rock respectively, with the highest readings for both parameters identified in MR1-1 sample. In the Liang Formation, the $S_{1}$ and $\mathrm{S}_{2}$ values are ranging from $0.03 \mathrm{mg} \mathrm{HC} / \mathrm{g}$ to $33.5 \mathrm{mg}$ $\mathrm{HC} / \mathrm{g}$ and $0.24 \mathrm{mg} \mathrm{HC} / \mathrm{g}$ rock to $45.3 \mathrm{mg} \mathrm{HC} / \mathrm{g}$ rock respectively. Low $\mathrm{S}_{1}$ readings are recorded for the coal and shale samples of the Miri Formation, amounting up to $1.42 \mathrm{mg}$ $\mathrm{HC} / \mathrm{g}$ rock. Shale samples display low $\mathrm{S}_{2}$ readings that are less than $1 \mathrm{mg} \mathrm{HC} / \mathrm{g}$ rock, while the $\mathrm{S}_{2}$ values for coal ranges from 36.3 to $121.5 \mathrm{mg} \mathrm{HC} / \mathrm{g}$ rock.

$T_{\max }$ is the temperature with the maximum generation of hydrocarbon. In the terrace deposits, $T_{\max }$ values range from 355 to $409{ }^{\circ} \mathrm{C}$, while the $T_{\max }$ values for the Liang Formation are ranging from 300 to $424{ }^{\circ} \mathrm{C}$ for all studied lithology. The $T_{\max }$ readings recorded for the Miri Formation ranges between 378 and $433{ }^{\circ} \mathrm{C}$ for all studied lithology. In the Setap Shale Formation, relatively high $T_{\text {max }}$ readings are recorded-with readings ranging from 432 to $437{ }^{\circ} \mathrm{C}$.

The PI values for the terrace deposits are low, with values that range from 0.05 to 0.16 . The PI values of the Liang 


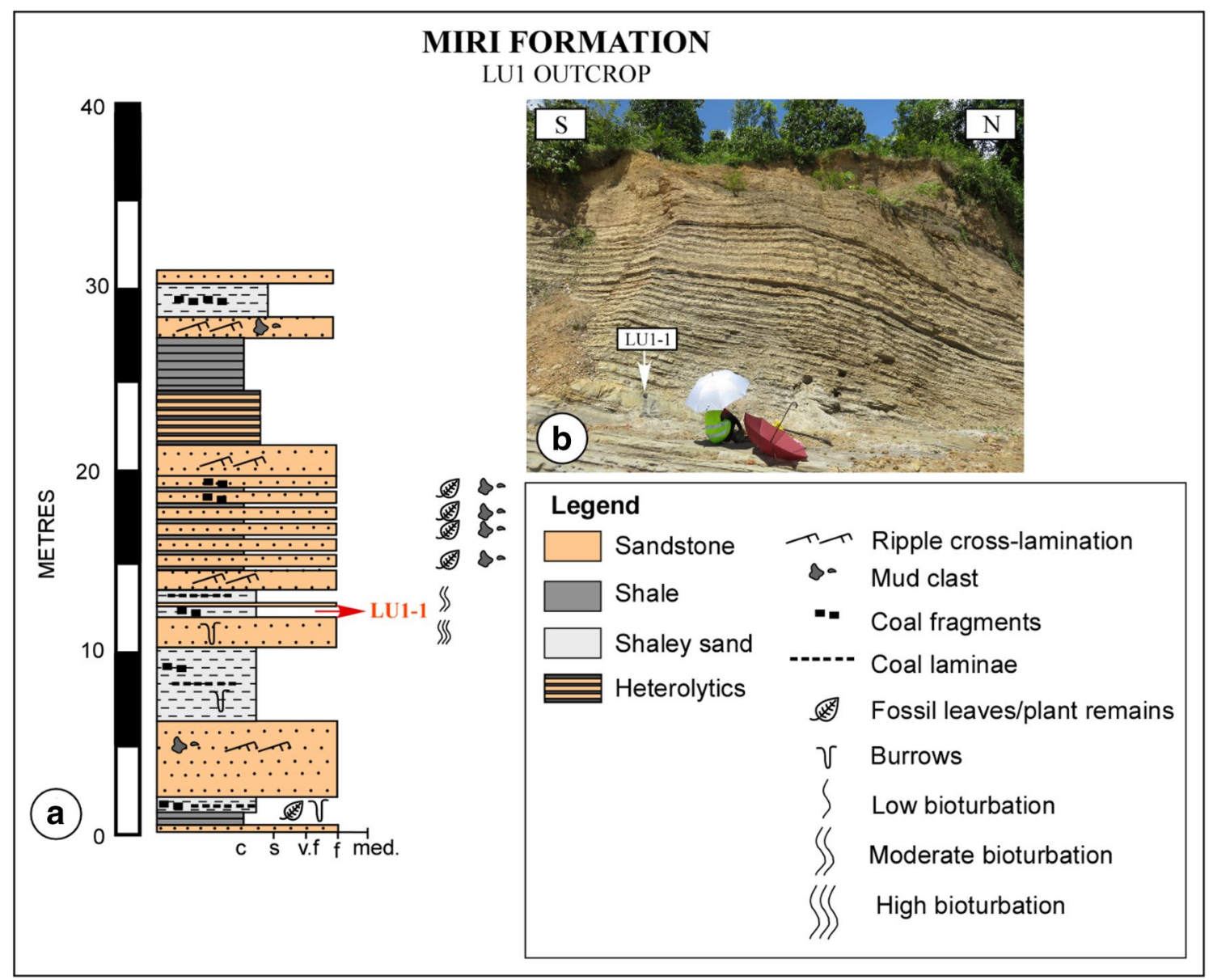

Fig. 5 a A representative lithostatigraphic column of the Miri Formation in the LU1 outcrop locality; b Site of collection for samples LU1- and LU1-2 in the study area

Formation are recorded to range from 0.07 to 0.43 , with the highest reading identified in BR2-5 sample. All samples of the Miri Formation contain low PI values that range from 0.01 to 0.07 . PI values in the Setap Shale averages to an amount of $0.79 \%$ and 0.08 respectively.

In the terrace deposit, coal sample MR1-1 has a high $\mathrm{HI}$ reading of $193 \mathrm{mg} \mathrm{HC} / \mathrm{g}$ TOC but a low OI of $29 \mathrm{mg} \mathrm{CO} 2 / \mathrm{g}$ TOC. Alternatively, the lignitic sand samples record high OI values that range from $209-252 \mathrm{CO} 2 / \mathrm{g}$ TOC and low $\mathrm{HI}$ readings that range from 14 to $17 \mathrm{mg} \mathrm{HC} / \mathrm{g}$ TOC. The $\mathrm{HI}$ values vary from 18 to $95 \mathrm{mg} \mathrm{HC/g}$ TOC, while the OI values for the Liang Formation are between $68 \mathrm{mg} \mathrm{CO} 2 / \mathrm{g}$ TOC and $229 \mathrm{mg} \mathrm{CO} 2 / \mathrm{g}$ TOC. A wide range of $\mathrm{HI}$ and OI values are recorded for the Miri Formation, ranging from 39 to $195 \mathrm{mg} \mathrm{HC} / \mathrm{g}$ TOC and 15 to $79 \mathrm{mg} \mathrm{CO} 2 / \mathrm{g}$ TOC respectively. The Setap Shale Formation contains OI and HI values ranging from 24 to $40 \mathrm{mg} \mathrm{CO} 2 / \mathrm{g}$ TOC and 77 to $93 \mathrm{mg}$ $\mathrm{HC} / \mathrm{g}$ TOC respectively.

An overall analysis indicates a preliminary interpretation that the coal samples of terrace deposit, Liang and Miri Formations have high TOC values. The lignitic sand samples of the terrace deposits serve as the second-best lithology in terms of TOC, as the values are relatively higher than other non-coal lithology. A range of $\mathrm{HI}$ values are recorded within the studied formations, with the coals of terrace deposit and Miri Formation containing high values of more than $100 \mathrm{mg}$ $\mathrm{HC} / \mathrm{g}$ TOC. Values for $T_{\text {max }}$ in coal samples from Liang and Miri formations as well as terrace deposits range from 300 to $404{ }^{\circ} \mathrm{C}$ in general, with the Setap Shale Formation having high $T_{\max }$ readings. The geochemical results are summarized in Table 2.

\section{Organic petrography}

Selected samples belonging to the terrace deposits, Liang, Miri and Setap Shale formations are analysed for the assemblage and abundance of macerals, as summarized in Table 3. For the terrace deposits, Liang and Miri formations, huminite is the predominant maceral group, averaging to $89.3 \%$, $95.5 \%$ and $72.5 \%$ respectively. In contrast, mineral matter component constitutes the highest constituent in Setap Shale 


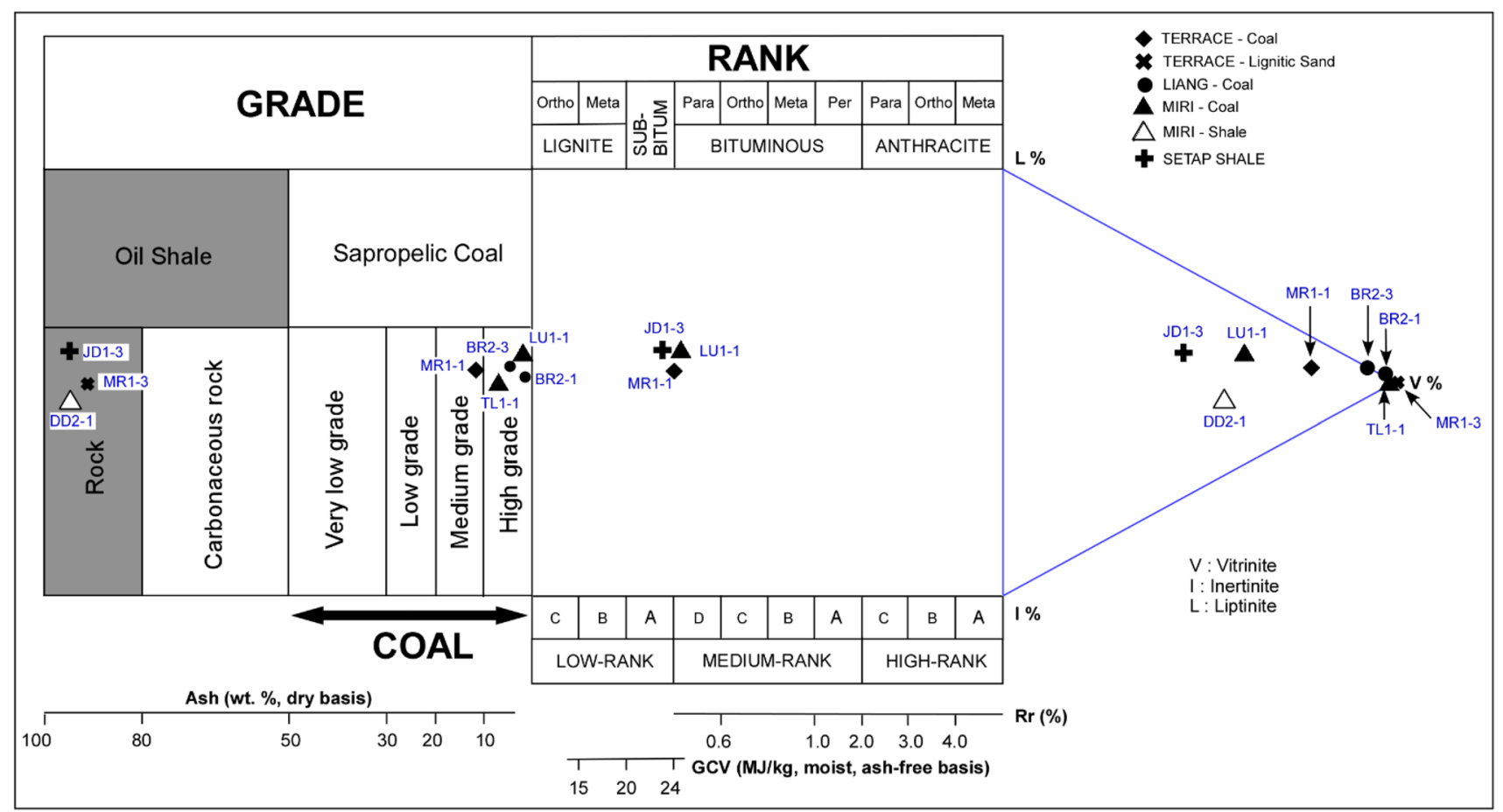

Fig. 6 Coal rank and grade determination using the ECE-UN (1998) classification

Formation, with an average value of $73 \%$, followed by huminite which makes up an average of $46 \%$.

Eu-ulminite B is the most abundant maceral in MR1-1 coal sample, comprising a value of $29.5 \%$ (Figs. 7a, b, c and e). This maceral is composed of closed cell lumens and cell walls that are created during humification (Diessel 1992). This maceral is also abundant in the Liang Formation, amounting to $73 \%$ as detected in BR2-1 sample (Figs. 9a, b, $\mathrm{d}$ and e). Eu-ulminite B is also present in the Miri Formation with values ranging from 9 to $80 \%$ (Fig. 10a).

Densinite is the second most abundant maceral in MR1-1 coal sample, having an average value of $18.5 \%$. (Figs. $7 \mathrm{a}, \mathrm{b}$ and $\mathrm{d} ; 8 \mathrm{a}$ and $\mathrm{c}$ ). The maceral densinite is composed of gelified small particles cemented by amorphous humic matter, with no fluorescence. However, this maceral is absent in the Liang Formation but are present in the Miri Formation, with values ranging from 2.5 to $36.5 \%$ (Figs. $10 \mathrm{a}, \mathrm{c}$ and e).

Similarly, attrinite is also absent in the Liang Formation but recorded in terrace deposits and Miri Formation. Attrinite comprises of a mixture of fine huminitic particles and ungelified amorphous huminitic substances (Sýkorová et al. 2005). In the MR1-1 and MR1-3 samples, attrinite is recorded with an average value of $11.5 \%$ and $7.5 \%$ respectively (Figs. 7d and e). In the Miri Formation, this maceral is present with values that range from 1 to $38.6 \%$.

Corpohuminite, which is made up of structureless features with filled with humic materials, is grey in colour and does not fluoresce (Sýkorová et al. 2005). This maceral averages to $7.5 \%$ in the coal sample of terrace deposits (Fig. 7e) and $23 \%$ in the Liang Formation, being the most abundant in samples BR2-1 and BR2-3 (Figs. 9a, c and d). In the Miri Formation, corpohuminite is present at $11 \%$ to $19 \%$ in composition.

Gelinite is a maceral formed from the reprecipitation of dissolved organic matter in a gel form. It is most abundant in MR1-3 sample of terrace deposit (81.5\%) and averages to $2 \%$ in the Liang Formation (Fig. 9b). In the Miri Formation, gelinite is also present $(2.8 \%)$.

The second most abundant maceral group present in the coals of terrace deposits, Liang, Miri formations is liptinite, constituting an average of $14 \%, 7.67 \%$ and $13.5 \%$ respectively. The dominating liptinite maceral in the terrace deposit is sporinite as recorded in MR1-1 sample with a value of $4 \%$ (Figs. $8 \mathrm{~b}$ and d). This maceral is present with an abundance of $1 \%$ and $2.5 \%$ in the Liang and Miri Formations respectively. Alginite is identified in terrace coal deposit with a value of $3 \%$ (Fig. 8b) and is absent in the Liang Formation. This maceral is present with an abundance of $6 \%$ in the Miri Formation (Figs. 10a, b and d). Petrographic results indicate the predominance of flattened discs of telalginite of dull yellow fluorescence in the samples.

Cutinite is a maceral that consists of fossil cuticles from leaves and stems (Pickel et al. 2017). This maceral is identified in the terrace coal sample, Liang and Miri Formations, 


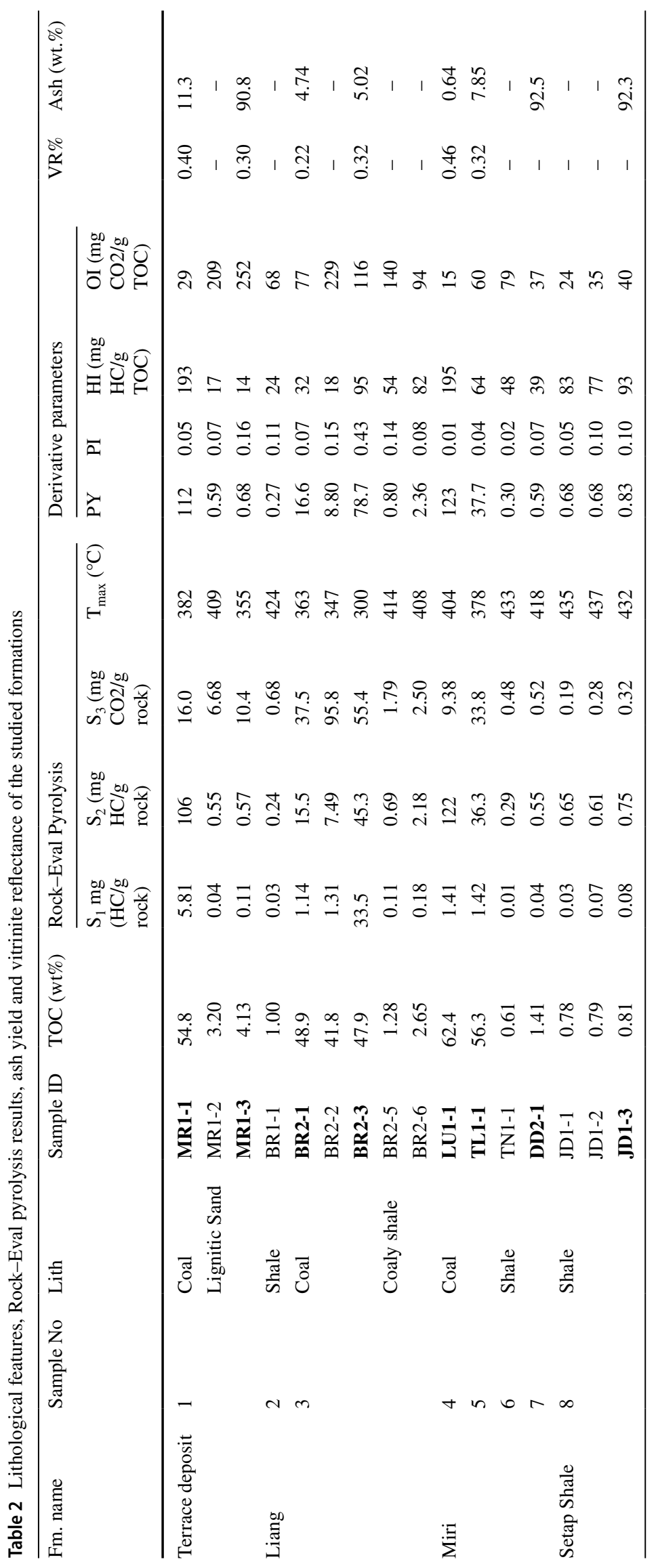


Table 3 Organic petrographic results showing the maceral constitution of the studied samples

\begin{tabular}{|c|c|c|c|c|c|c|c|c|c|c|}
\hline \multirow{2}{*}{\multicolumn{3}{|c|}{$\frac{\text { Formation name }}{\text { Sample ID/Maceral type }}$}} & \multicolumn{2}{|c|}{ Terrace deposits } & \multicolumn{2}{|l|}{ Liang } & \multicolumn{3}{|l|}{ Miri } & \multirow{2}{*}{$\begin{array}{l}\text { Setap Shale } \\
\text { JD1-3 }\end{array}$} \\
\hline & & & MR1-1 & MR1-3 & BR2-1 & $\mathrm{v}$ & LU11 & TL1-1 & DD2-1 & \\
\hline \multirow[t]{12}{*}{ Huminite } & \multirow[t]{5}{*}{ Telohuminite } & Textinite B & 1.0 & - & - & - & - & - & - & - \\
\hline & & Texto-ulminite & 4.0 & - & - & - & - & - & 2.0 & - \\
\hline & & Eu-ulminite A & & - & - & - & - & - & 2.0 & - \\
\hline & & Eu-ulminite B & 29.5 & 5.5 & 73.0 & 70.0 & 10.5 & 80.0 & 9.0 & - \\
\hline & & Total & 34.5 & 5.5 & 73.0 & 70.0 & 10.5 & 80.0 & 13.0 & 0.0 \\
\hline & \multirow[t]{3}{*}{ Detrohuminite } & Attrinite & 11.5 & 7.5 & - & - & 1.0 & - & 38.5 & 46.0 \\
\hline & & Densinite & 18.5 & 2.0 & - & - & 36.5 & - & 2.5 & - \\
\hline & & Total & 30.0 & 9.5 & & & 37.5 & & 41.0 & 46.0 \\
\hline & \multirow[t]{3}{*}{ Gelohuminite } & Gelinite & 2.5 & 81.5 & 2.0 & - & 3.0 & - & 2.5 & - \\
\hline & & Corphuminite & 11.5 & 3.5 & 23.0 & 23.0 & 11.0 & 19.0 & - & - \\
\hline & & Total & 14.0 & 85.0 & 25.0 & 23.0 & 14.0 & 19.0 & 2.5 & \\
\hline & \multicolumn{2}{|l|}{ Total } & 78.5 & 100.0 & 98.0 & 93.0 & 62.0 & 99.0 & 56.5 & 46.0 \\
\hline \multirow[t]{6}{*}{ Inertinite } & & Fusinite & - & - & - & - & & - & 9.0 & - \\
\hline & & Semifusinite & 2.0 & - & - & - & 2.0 & - & - & - \\
\hline & & Funginite & 3.5 & - & - & - & 6.0 & - & - & - \\
\hline & & Secretinite & 0.5 & - & - & - & 0.5 & - & - & - \\
\hline & & Inertodetrinite & 1.5 & - & - & - & 3.5 & - & 16.0 & 20.0 \\
\hline & & Total & 7.5 & - & - & - & 12.0 & - & 25.0 & 20.0 \\
\hline \multirow{8}{*}{\multicolumn{2}{|c|}{ Liptinite }} & Sporinite & 4.0 & - & - & 1.0 & 2.0 & - & 2.5 & - \\
\hline & & Cutinite & 2.0 & - & - & 1.0 & 8.0 & - & 2.5 & - \\
\hline & & Alginite & 3.0 & - & - & - & 6.0 & - & - & 8.0 \\
\hline & & Suberinite & 1.5 & - & 2.0 & 5.0 & 6.0 & - & - & - \\
\hline & & Resinite & 1.5 & - & - & - & 1.0 & - & - & - \\
\hline & & Bituminite & & - & - & - & - & - & 4.5 & 3.0 \\
\hline & & Liptodetrinite & 2.0 & - & - & - & 3.0 & 1.0 & 9.0 & 23.0 \\
\hline & & Total & 14.0 & 0.0 & 2.0 & 7.0 & 26.0 & 1.0 & 18.5 & 34.0 \\
\hline \multirow{5}{*}{\multicolumn{2}{|c|}{ Mineral matter }} & Carbonates & 0.5 & 15.0 & - & - & - & - & 6.9 & 1.0 \\
\hline & & Pyrite & 3.0 & - & 1.0 & 1.0 & 3.0 & 3.0 & 3.4 & 2.0 \\
\hline & & Clays & - & - & - & - & 2.0 & - & 68.0 & 70.0 \\
\hline & & Other silicates & - & 50.0 & - & - & - & - & - & - \\
\hline & & Total & 3.6 & 65.0 & 1.0 & 1.0 & 5.0 & 3.0 & 78.3 & 73.0 \\
\hline
\end{tabular}

with abundances amounting up to 5.3\% (Figs. 7e and f; Figs. 8c, e and f; Fig. 9c and e; Figs. 10a, d, e and f).

Suberinite is a maceral that originates from suberin of cork tissues (Pickel et al. 2017). This maceral makes up 1.5\% of the terrace deposit coal sample. In the Liang Formation, suberinite is recorded to have an abundance of $2.5 \%$. Maceral analysis indicates that the Miri Formation is made up of $6 \%$ of suberinite. Other liptinite macerals present are resinite (Figs. 10c and d), bituminite and liptodetrinite.

Inertinite macerals are present in all studied deposits, except for the samples in the Liang Formation. Inertodetrinite is composed of small inertinite fragments that are remnants produced from wildfires (ICCP 2001). This maceral is amounting to $2 \%, 16 \%$ and $20 \%$ in the terrace deposits, Miri and Setap Shale Formations respectively.
The most abundant inertinite maceral in the terrace deposit is funginite, a maceral that consists of fungal remains, including fungal spores, sclerotia, hyphae and mycelia (ICCP 2001). Funginite is most abundant in MR1-1 sample, amounting up to $3.5 \%$ (Figs. $7 \mathrm{a}, \mathrm{b}$ and d). Funginite makes up 6\% of the Miri Formation (Fig. 9f; Fig. 10c). Semifusinite is made of woody tissues that are partially heated and constitutes an abundance of $2 \%$ in both terrace deposits and Miri Formations (Fig. 9f).

Carbonates are detected in terrace deposits, Miri and Setap Shale Formations, with the highest volume recorded in the MR1-3 sample of the terrace deposit. Pyrite is identified with an average value of $3 \%, 1 \%, 3.13 \%$ and $2 \%$ in the terrace deposits, Liang, Miri and Setap Shale formations 
Fig. 7 Photomicrographs of the maceral eu-ulminite in the terrace deposit under a reflected white light and $\mathbf{b}$ UV light, together with densinite and funginite; $\mathbf{c}$ Eu-ulminite occurring with pyrite; $\mathbf{d}$ Fine huminitic particles of attrinite, observed together with funginite and small gelified particles of densinite under white light; e Structureless corpohuminite under white light, together with eu-ulminite, attrinite and cutinite; f Cutinite displaying serrated bands that fluoresces greenish-yellow under blue light
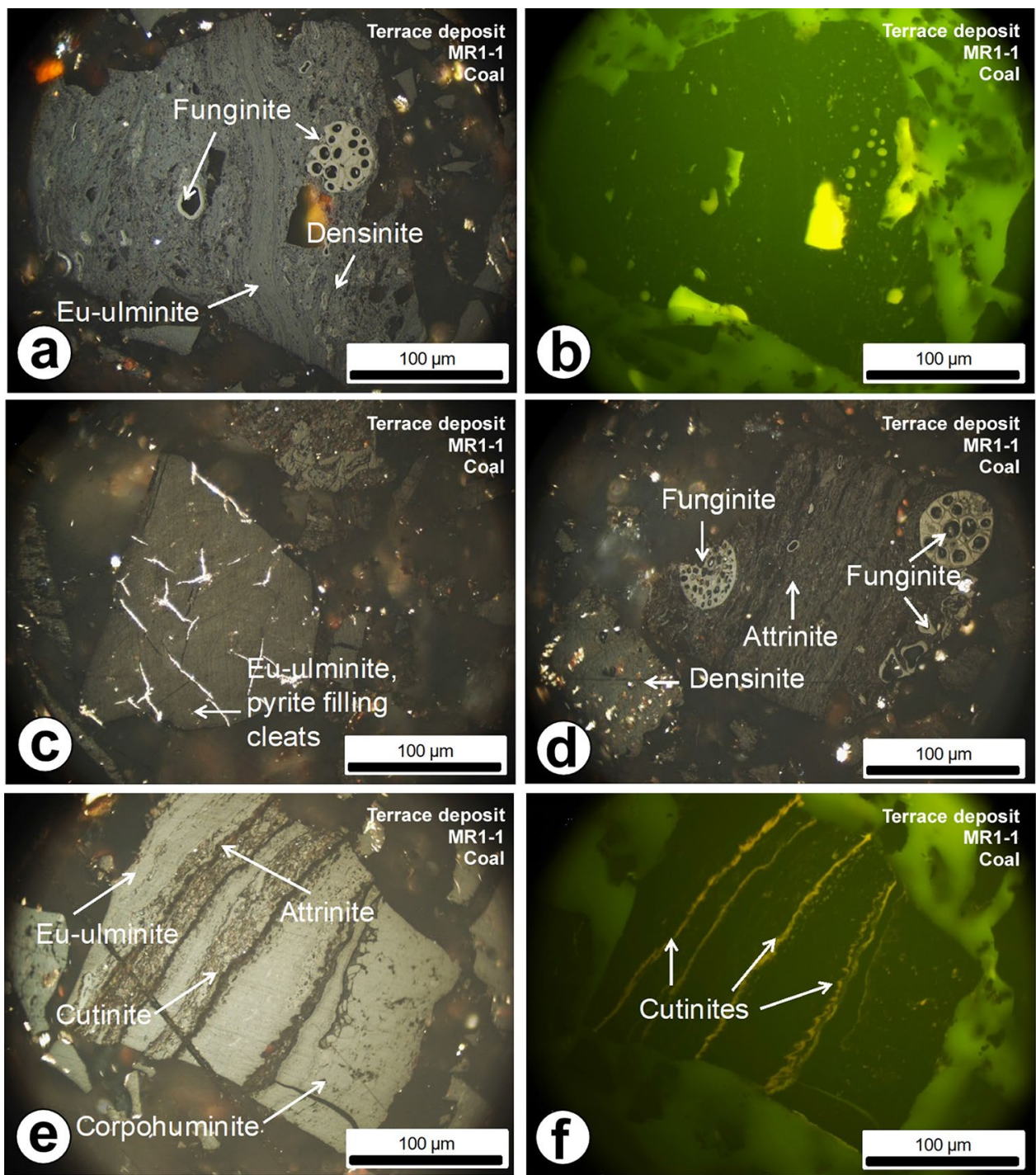

respectively. For Miri and Setap Shale Formations, clay constitutes more than $50 \%$ in the samples.

As a deep marine formation, very few macerals are detected in the samples of the Setap Shale Formation. Huminite and inertinite macerals are identified as fragments within the mainly clayey matrix of the sample. The sample records $46 \%$ of attrinite, followed by $23 \%$ of liptodetrinite and $20 \%$ of inertodetrinite. The sample is dominated by clay (70\%), with pyrite and carbonates occurring in low amounts of $2 \%$ and $1 \%$ respectively. The clay matrix is observed to be fluorescing, indicating the possibility of bituminite within the sample.

In this study, the mean random vitrinite reflectance for the terrace deposits, Liang and Miri formations were measured in eu-ulminite and recorded to range from 0.22 to $0.46 \%$ (Table 3). Ash yields of selected samples show that very high ash values of more than $90 \%$ are recorded for MR1-3, DD2-1 and JD1-3. Other samples contain ash yields that range from 0.64 to $12.2 \%$, with the lowest value belonging to LU1-1 sample.

\section{Biomarker distribution}

To further validate results obtained from Rock-Eval pyrolysis and organic petrography to, a total of five samples were selected for biomarkers analysis. One sample derived from terrace deposit (MR1-1), two samples obtained from the Liang Formation (BR2-1 and BR2-3), one sample derived from the Miri Formation (LU1-1) and one sample taken from the Setap Shale Formation (JD1-3) were chosen for biomarkers analysis.

Biological markers, or best known as biomarkers, are composed of complex molecular fossils generated from once-living organisms and can be found in source rock extracts (Peters et al. 2007a). Biomarker data are one of the 
Fig. 8 Photomicrographs of the coal samples in the terrace deposit under white and UV lights, illustrating the; a Densinite displaying light gray colour in reflected light; b Flattened discs of alginite and sporinite in fluorescence mode; $\mathbf{c}$ Dark gray cutinite under white light, ocurring alongside densinite and eu-ulminite; d Greenishyellow cutinite together with alginites, which exhibits similar fluoresence and sporinite; $\mathbf{e}$ Semifusinite occuring together with cutinite and eu-ulminite; $\mathbf{f}$ Cutinite and liptodetrinite that fluoresces in dark yellow under blue light
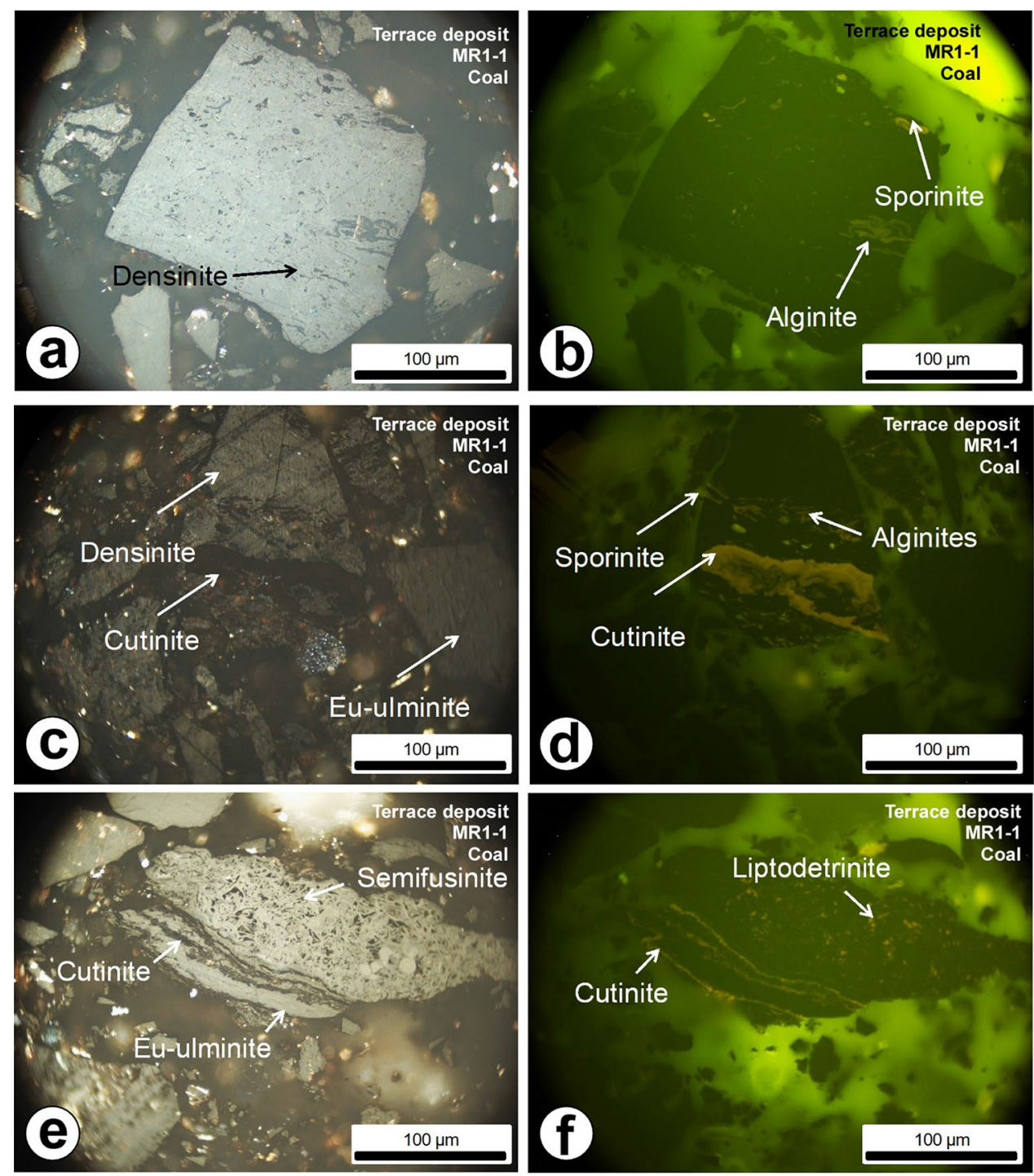

important means to assess a source rock's palaeodepositional environment and thermal maturity.

\section{Rock extraction and fractionation}

The coal sample from terrace deposit records a high extract yield of $74.5 \mathrm{mg} \mathrm{HC} / \mathrm{g}$ rock. Among the two coal samples from the Liang Formation, sample BR2-3 has the highest extract yield (bitumen) with a value of $89.3 \mathrm{mg} \mathrm{HC} / \mathrm{g}$ rock. In the Miri Formation, sample LU1-1 also display a high extract yield value of $57.1 \mathrm{mg} \mathrm{HC/g}$ rock. Sample JD1-3 display a very low extract yield of less than $1 \mathrm{mg} \mathrm{HC} / \mathrm{g}$ rock. For all samples except JD1-3, there is a higher percentage of asphaltene over maltene (Table 4).

Among the analyzed samples, the highest aromatic content was identified in sample MR1-1, with a value of $45 \%$ while sample BR2-1 is composed of almost entirely of asphaltene (99\%). Polar compounds are generally high for samples MR1-1, BR2-3 and LU1-1, with the highest value identified with BR2-3 of 82\% (Table 4). For the Miri Formation, sample LU1-1 display high asphaltene (95\%) and polar compounds $(61 \%)$.

\section{n-alkanes and isoprenoids}

Gas chromatogram fingerprints of $n$-alkanes is used to identify source of organic matter (Peters et al. 2007a), by examining the mode and skewness of $n$-alkanes identified in a sample. Organic matter associated with a terrestrial source display a bimodal distribution of $n$-alkanes and skew toward $n-\mathrm{C}_{23}-n-\mathrm{C}_{31}$ (Eglinton and Hamilton 1967). Lacustrine and marine oils from shaly source rocks are reflected by the odd-predominance of $n$-alkanes (Peters et al. 2007a). 
Fig. 9 Photomicrographs of the Liang and Miri formations displaying the occurrence of; a Ulminite and corpohuminite under white light, together with; b Pori-gelinite under reflected light; c Serrated bands of cutinite in the Miri Formation together with corpohuminite; d Elogated bodies of corpohuminite observed under white light with ulminite; e Thicker bands of cutinite under white light, together with densinite, inertodetrinite, ulminite and secretinite, which is displayed as highly reflected round particles; f Uni- and multicellular funginite maceral occurring with secretinite and semifusinite, as well as densinite under white light
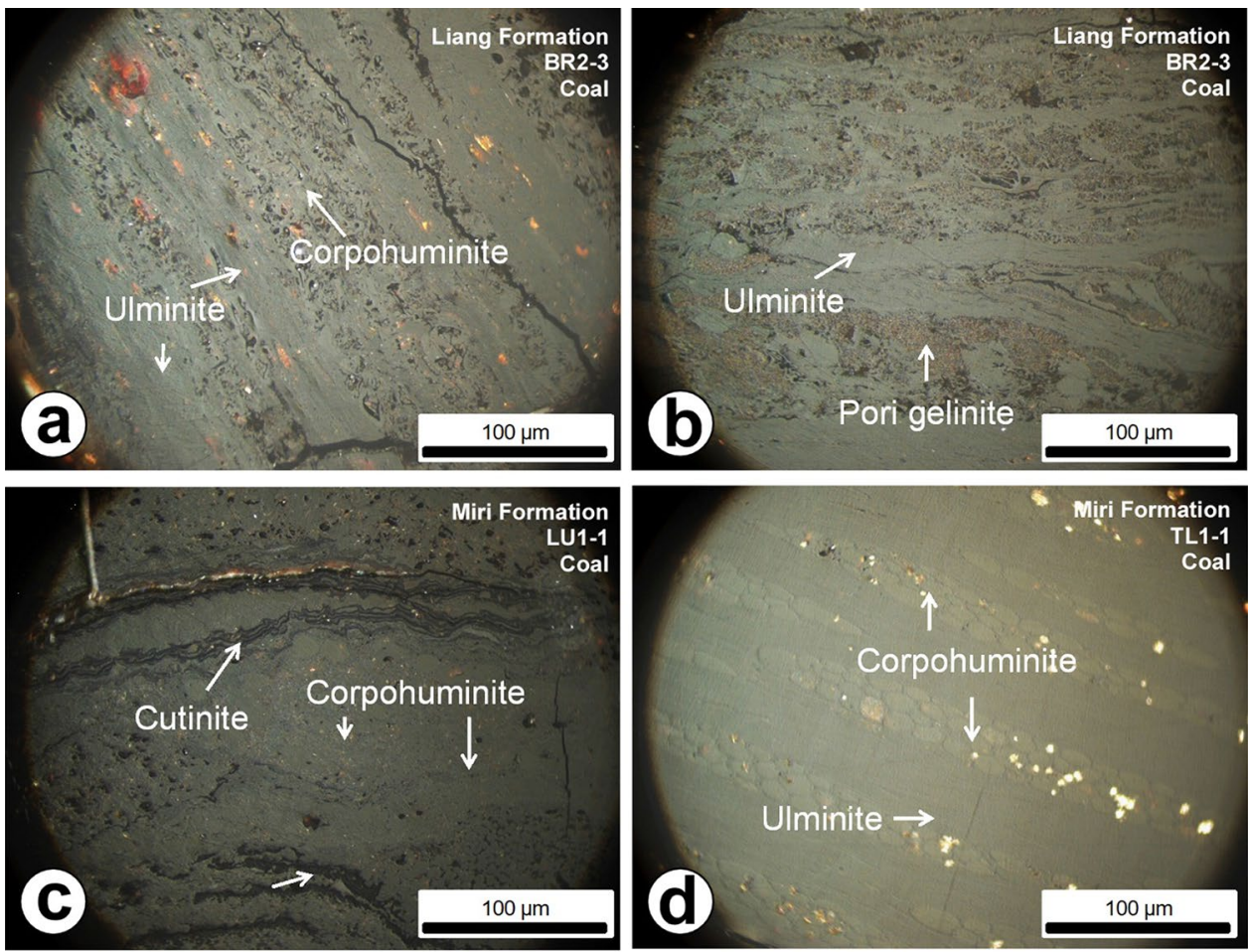

Miri Formation TL1-1
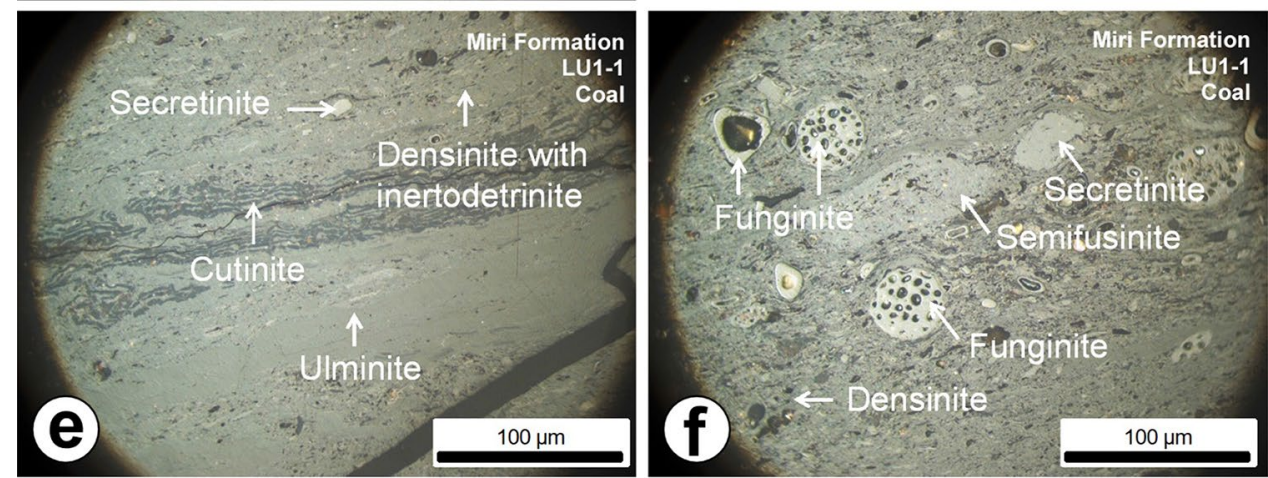

Distribution of $n$-alkanes for selected samples from terrace deposits, Liang and Miri formations are illustrated in Fig. 11. The GC-MS chromatograms of sample MR1-1 show an evident bi-modal distribution with high concentrations of $n-\mathrm{C}_{27}, n-\mathrm{C}_{29}, n-\mathrm{C}_{31}$ and $n-\mathrm{C}_{33}$ (Fig. 12a). Meanwhile, samples BR2-3 of the Liang Formation and LU1-1 of the Miri Formation display a normal distribution of $n$-alkanes (Figs. $11 \mathrm{~b}$ and c). Among the studied samples, sample LU1-1 has the highest pristane (Pr) and phytane $(\mathrm{Ph})$ values of 15.7 and 1.4 respectively, leading to high $\mathrm{Pr} / \mathrm{Ph}$ value of 11.2 (Table 5).

\section{Discussion}

\section{Type of organic matter-kerogen type}

Sediments of the terrace deposit, Liang, Miri and Setap Shale formations are classified based on the ECE-UN (1998) classification scheme which takes into account the sediments' ash content and vitrinite reflectance values (Fig. 6). Ash content of the studied Formations identify the coals as high grade (BR2-1, BR2-3, LU1-1 and TL1-1) to medium grade (MR1-1). Meanwhile, the shale samples of Miri and Setap Shale formations are characterized as carbonaceous rocks due to the high ash yields of the samples exceeding 90\% (Fig. 6).

Proportions of main maceral groups present in the studied deposits gave an impression regarding possible kerogen types present in the studied formations. A ternary diagram involving the main maceral groups in Fig. 12 shows that the 
Fig. 10 Photomicrographs of the Miri Formation showing; a Discs of alginite and cutinite bands under reflected light in the Miri Formation; b Alginite showing yellow fluorescence in UV light; c Oval-shaped resinite fluorescing in greenish-yellow, together with alginite and cutinite that exhibits strong yellow fluorescence under blue light; e and $\mathbf{f}$ Serrated cutinite bands under white and blue light
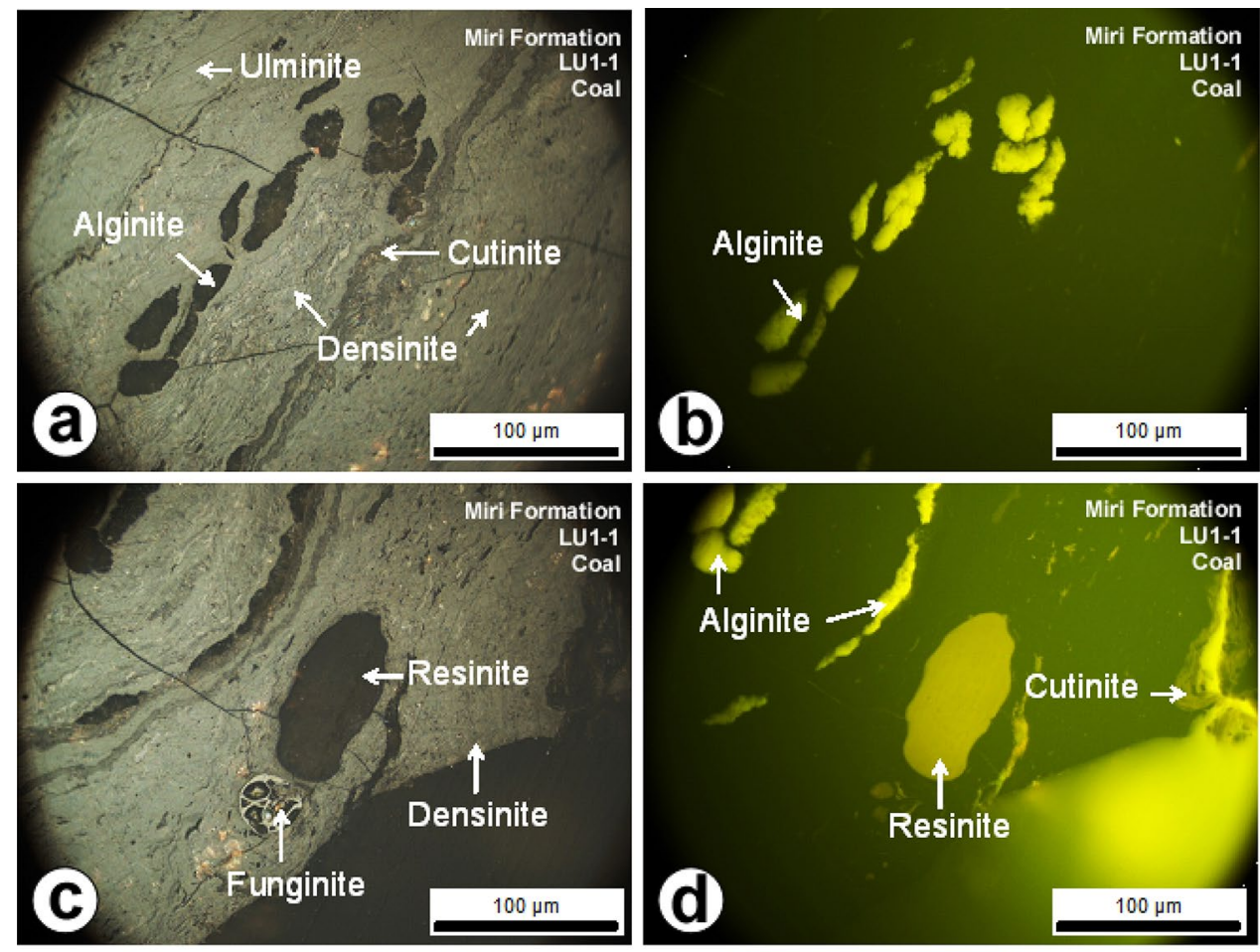

Miri Formation
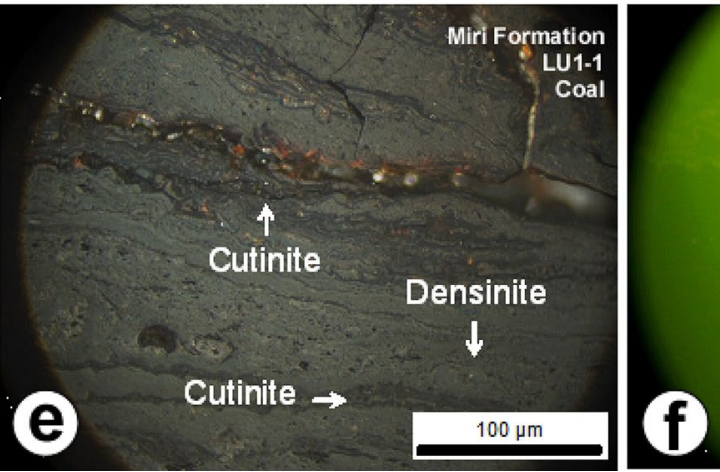

Miri Formation LU1-1 Coal

\begin{tabular}{|c|c|c|c|c|c|c|c|}
\hline Formation & Sample & $\begin{array}{l}\text { Extract yield } \\
(\mathrm{mg} / \mathrm{g})\end{array}$ & $\begin{array}{l}\text { Maltenes } \\
\text { (wt.\%) }\end{array}$ & Asphaltenes & $\begin{array}{l}\text { Saturates } \\
\text { (wt.\%) }\end{array}$ & Aromatics & $\mathrm{NSO}$ \\
\hline Terrace deposits & MR1-1 & 74.46 & 35.8 & 64.2 & 12 & 45 & 43 \\
\hline \multirow[t]{2}{*}{ Liang } & BR2-1 & 23.11 & 0.6 & 99.4 & - & - & - \\
\hline & BR2-3 & 89.34 & 15.8 & 84.2 & 3 & 14 & 82 \\
\hline Miri & LU1-1 & 57.12 & 4.5 & 95.5 & 21 & 18 & 61 \\
\hline Setap Shale & JD1-3 & 0.60 & - & - & - & - & - \\
\hline
\end{tabular}

Table 4 Extraction, de-asphaltening and fractionation results for all studied samples the kerogen types present in the studied formations. In a cross-plot of $\mathrm{S}_{2}$ versus TOC (Fig. 13), the kerogen types present in samples of different lithologies from the studied formations vary from dry gas prone, type II-III (mixed oil and gas) and type III (gas prone). The MR1-1 coal sample from the terrace deposit contain kerogen type II-III (mixed oil gas prone), while the lignitic sand samples are dry gas prone. In the Liang Formation, kerogen type III is present 

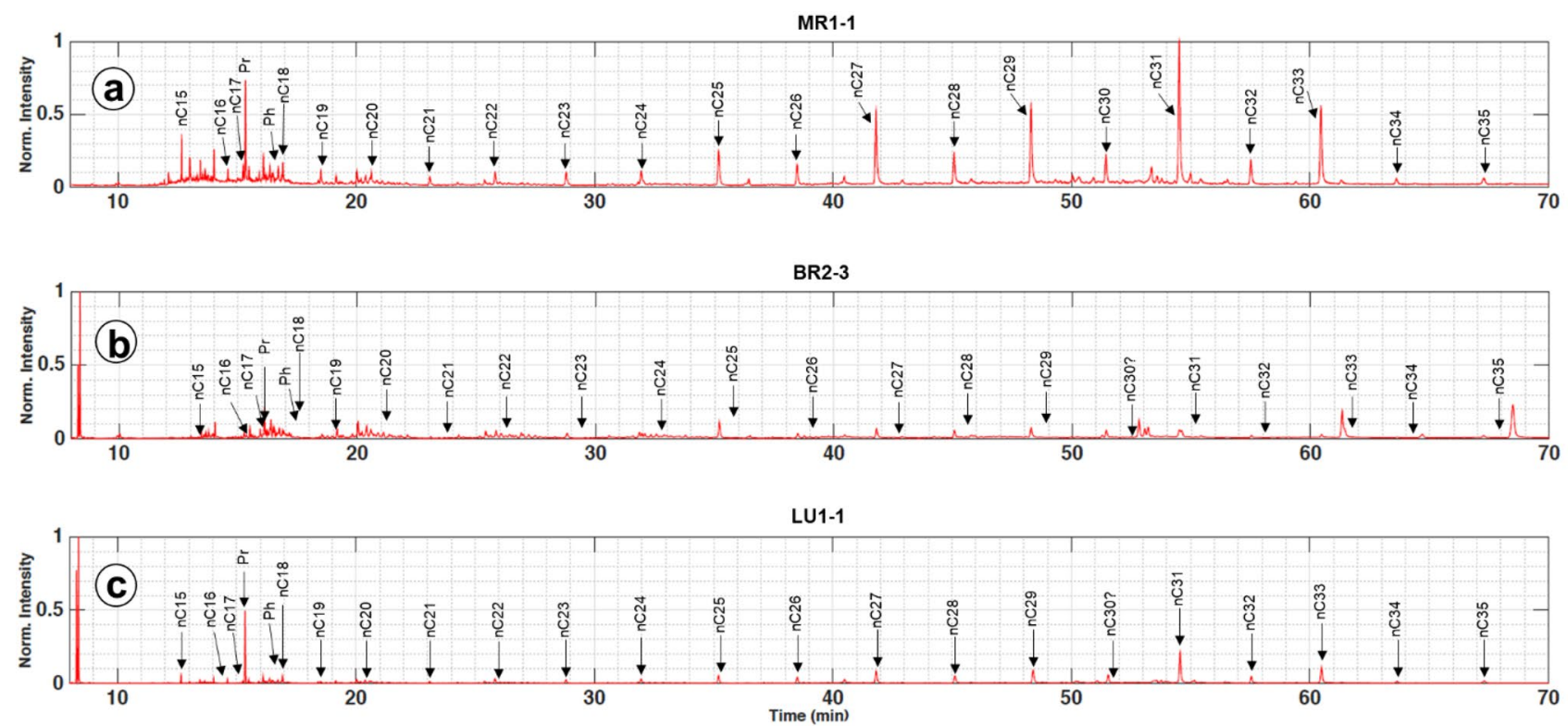

Fig. 11 a, b and $\mathbf{c}$ Gas chromatograms of saturate fractions of samples from terrace (a), Liang (b) and Miri (c) Formations

Fig. 12 A ternary diagram illustrating the type of kerogen available in the terrace deposit, Liang and Miri formations using the distribution of maceral composition (modified after Tissot and Welte 1984)

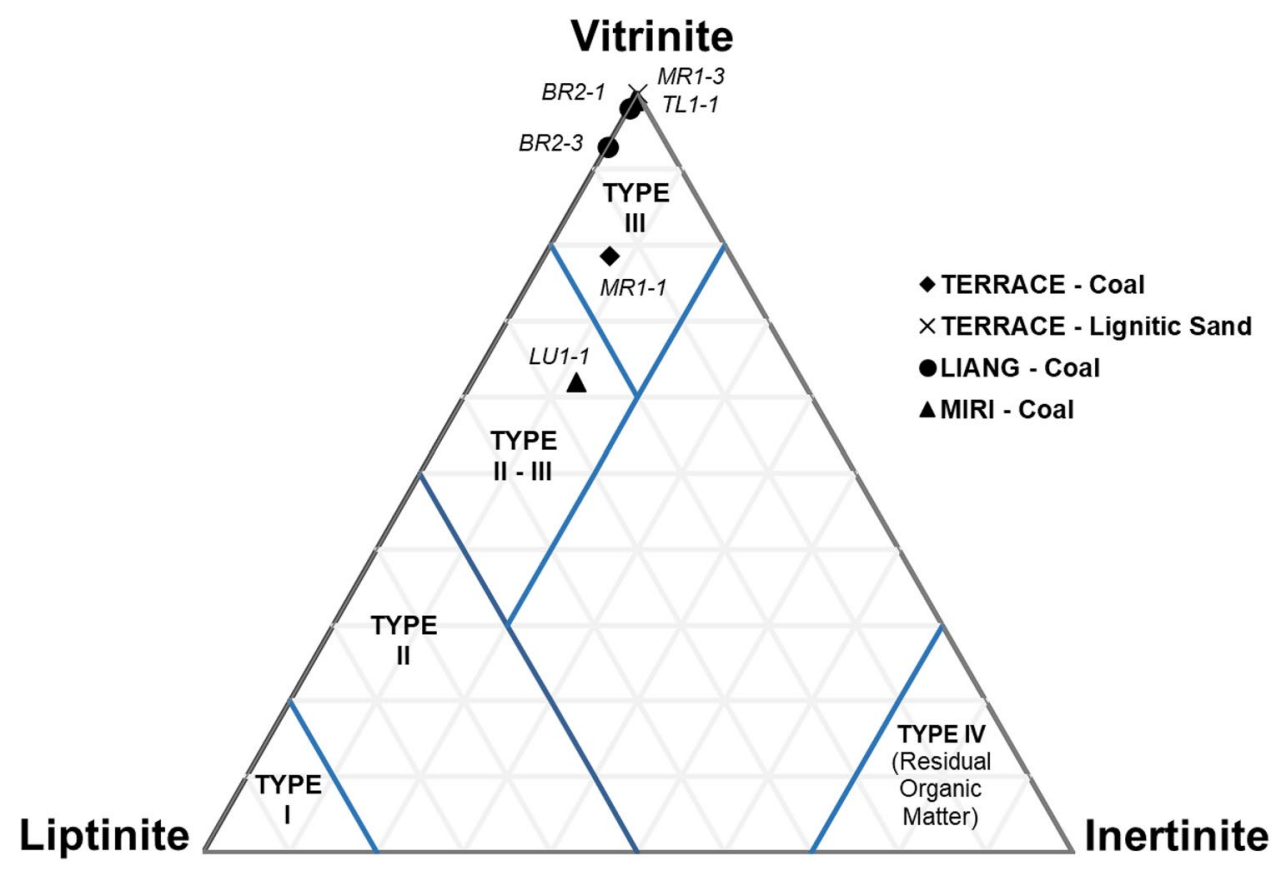

Table 5 Calculated n-alkane and isoprenoid ratios for the studied samples

\begin{tabular}{lccllllll}
\hline Formation & Sample & $\mathrm{Pr} / \mathrm{Ph}$ & $\mathrm{Pr} / \mathrm{nC}_{17}$ & $\mathrm{Ph} / \mathrm{nC}_{18}$ & $\mathrm{R}_{22}$ & $\mathrm{P}_{\mathrm{aq}}$ & $\mathrm{nC}_{19} / \mathrm{nC}_{31}$ & $\mathrm{CPI}$ \\
\hline Terrace deposits & $\mathrm{MR} 1-1$ & 6.81 & 7 & 1.14 & 1.05 & 0.15 & 0.034 & 3.77 \\
Liang & $\mathrm{BR} 2-3$ & - & 0 & 0 & 1.86 & 0.39 & 0 & 2.11 \\
Miri & $\mathrm{LU} 1-1$ & 11.2 & 28.5 & 2.46 & 1.36 & 0.16 & 0.018 & 2.64 \\
\hline
\end{tabular}




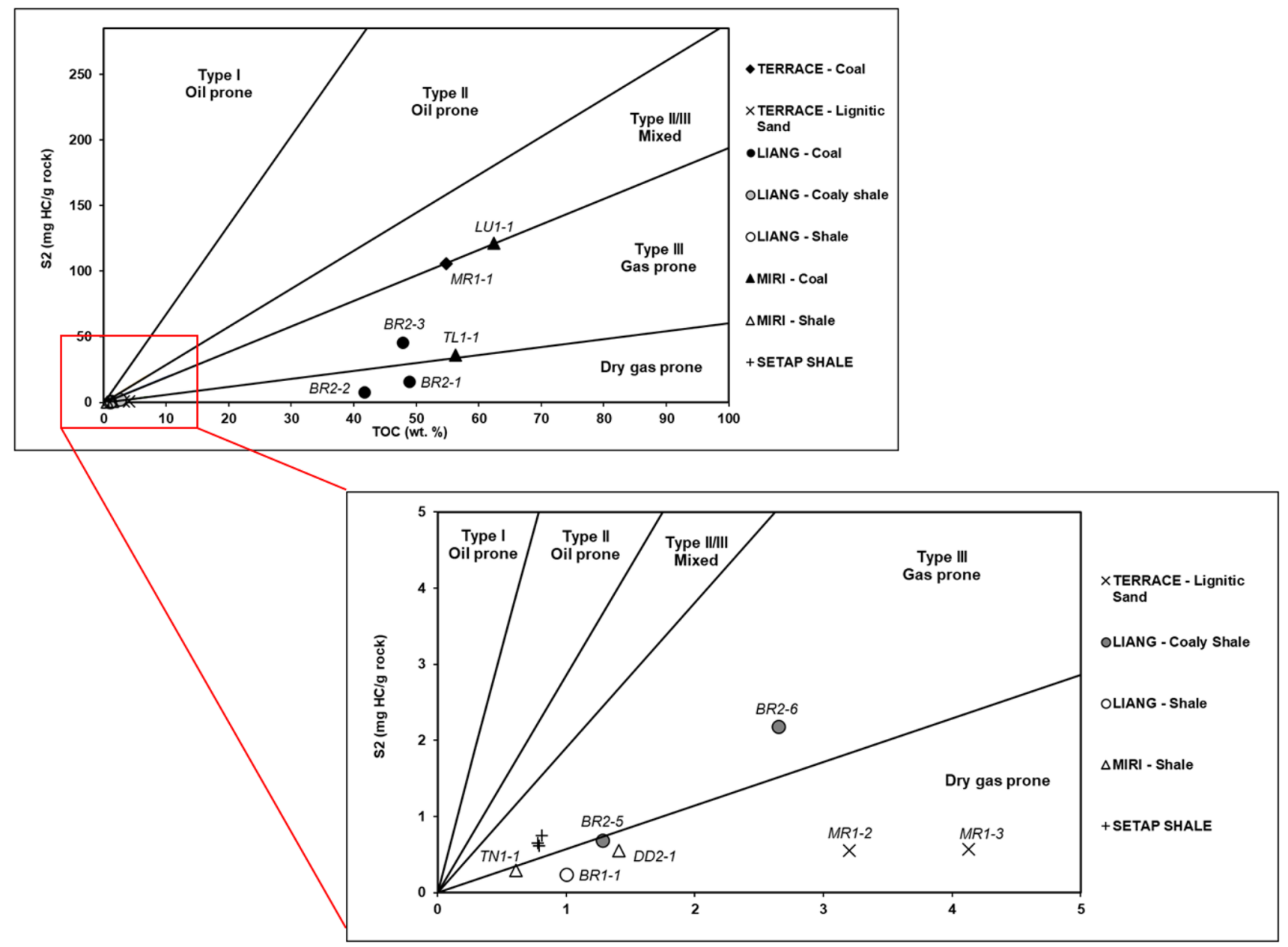

Fig. 13 A cross-plot of $S_{2}$ versus TOC to identify the kerogen types available in the studied formations (Langford and Blanc-Valleron 1990)

in samples BR2-3, BR2-5 and BR2-6, whereas dry gas is present in BR2-1, BR2-2 and BR1-1 samples. The LU1-1 and TL1-1 coal samples from the Miri Formation contain kerogen types II-III (mixed oil and gas prone) and type III (gas prone). However, the shale samples of this formation contain dry gas. All Setap Shale Formation samples are gas prone.

A more precise method of identifying types of organic matter present in sample is accomplished by using the modified Van Krevelen diagram, which utilizes the parameters HI and OI. The cross-plot between both parameters in Fig. 14 agrees with the results in Fig. 13, in which the LU1-1 and MR1-1 samples of the Miri Formation and terrace deposit respectively contain kerogen type II-III (mixed oil and gas). Kerogen type III (gas prone) is present for TL1-1 (Miri Formation), BR2-3 (Liang Formation), BR2-6 (Liang Formation) and all Setap Shale samples. For the rest of the samples, they fall under the region of kerogen type IV, which is equivalent to dry gas.

\section{Palaeodepositional environment}

The types, abundance and distribution of macerals present in coals will reflect the palaeofacies and conditions in which the peat was previously deposited (Shalaby et al. 2019). In this study, two facies models are constructed according to Calder et al. (1991) and Diessel (1992), modified by Kalaitzidis et al. (2004; 2010). Four parameters are examined in these coal facies diagrams; tissue preservation index (TPI), gelification index (GI), Groundwater index (GWI) and vegetation index (VI).

The state of plant tissue preservation is demonstrated in TPI, whereas GI reflects the degree of wet or dry conditions in the peat-forming site (Diessel 1992). Wet environments in peat formation is indicated by high GI values, which can be affected by factors such as basin subsidence rate and groundwater table changes (Diessel 1992). In this study, the TPI and GI values are calculated based on Kalaitzidis et al. $(2004 ; 2010)$ to reflect low rank coals. The coal samples in this study contain TPI values that range from 0 to 1.4 , except 
Fig. 14 A cross-plot of HI versus OI in the modified Van Krevelen diagram to illustrate the type of kerogen available in the studied formations (Modified after Espitalié et al. 1985)

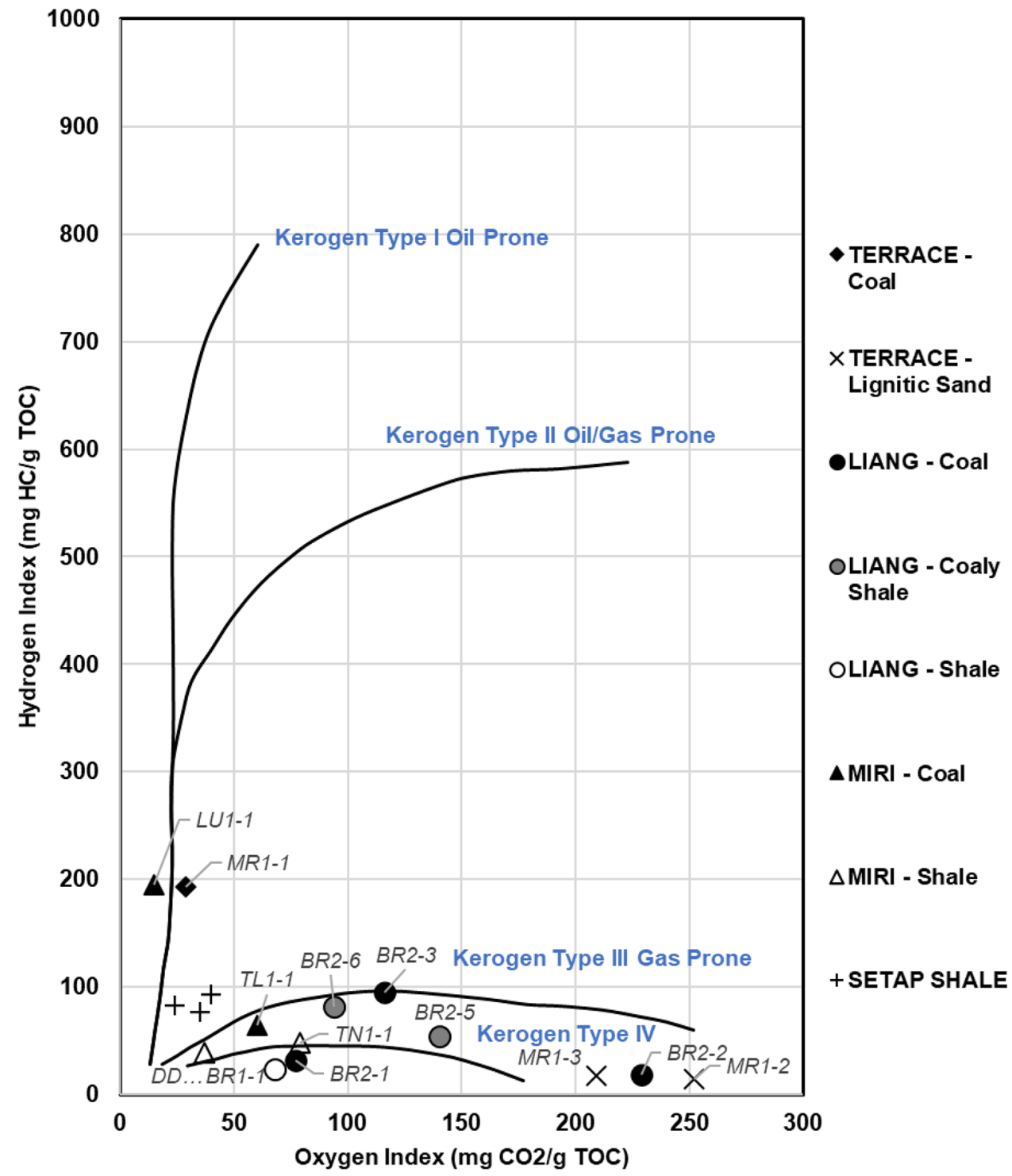

samples BR2-1, BR2-3 and TL1-1, in which very high values are identified. A range of GI values are recorded, reflecting different degrees of gelification, with samples BR2-1, BR2-3 and TL1-1 containing the highest values of more than 80. All calculated TPI and GI values from the terrace deposit, Liang and Miri formations coal samples are plotted together in a cross-plot between GI versus TPI in Fig. 15 (a), to illustrate the depositional facies of the samples. An overall assessment indicate that the coals are generally deposited in a lower to upper delta plain setting under limnic to limnotelmatic conditions. Contrary to the sample lithology, DD2-1 is shown to be deposited in an environment that is less water-saturated.

The hydrological state of a palaeomire is a useful tool to assess the depositional facies of coals, as changes in water input can cause alteration in the maceral composition. Therefore, a cross-plot of the groundwater index and vegetation index is constructed to illustrate the hydrological regime of a palaeomire (Fig. 15b). In this study, the GWI values for terrace deposit are 0.784 and 11.7, while an average value of 0.35 is recorded for the Liang Formation. The Miri Formation records GWI ranging from 0.28 to 4.85 .

The high GI, TPI and VI values identified in BR2-1, BR2-3 and TL1-1 are attributed to the preservation of root systems which are predominant in these samples. For the rest of the samples for the studied formations, the main plant input is of herbaceous plants which is reflected by the low VI values. The site of deposition for most of the coal sample has a high water table with possible marine influence as reflected by the presence of pyrite in most samples. This is fitting with the lower to upper delta plain setting as identified in the cross-plots.

Several ratios based on gas chromatographic results can be used for studying the palaeodepositional conditions. Ratio

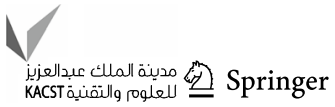


Fig. 15 Identification of palaeodepositional environment through; a GI versus TPI plot of the studied samples (after Diessel 1992, modified by Kalaitzidis et al. 2004); b GWI versus VI plot (after Calder et al. 1991, modified by Kalaitzidis et al. 2004)
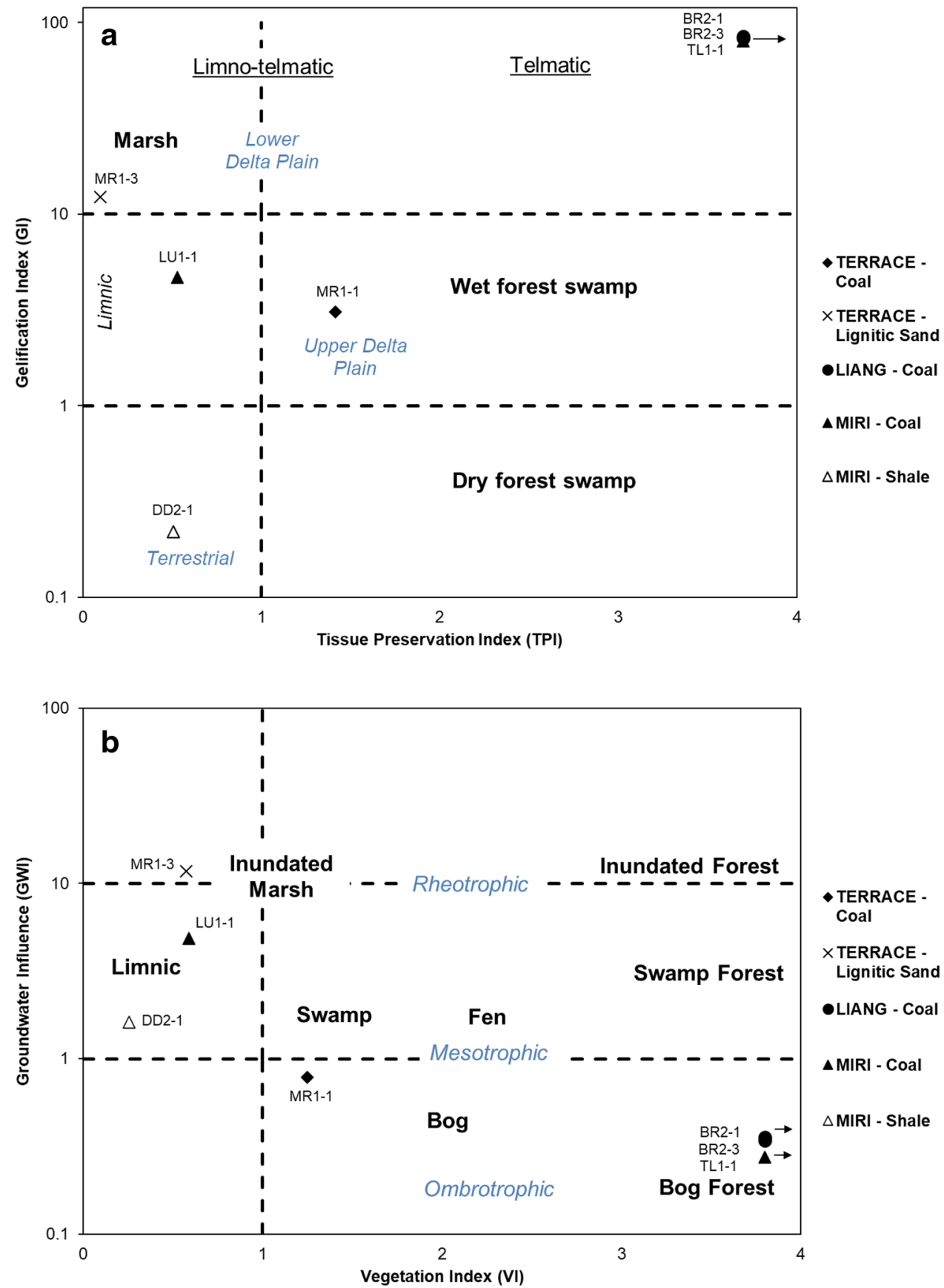

of pristane to phytane $(\mathrm{Pr} / \mathrm{Ph})$ is a useful tool to detect the depositional facies of coals, in which a $\mathrm{Pr} / \mathrm{Ph}$ value of less than 1 indicates a reducing and anoxic environment (Powell and McKirdy 1973; Didyk et al. 1978). An oxic to suboxic depositional condition is identified from a $\mathrm{Pr} / \mathrm{Ph}$ value of more than 3 (Peters et al. 2007b), whereas a value of more than 10 is indicative of a peat swamp environment. In this study, samples MR1-1 and LU1-1 have Pr/Ph values of 6.81 and 11.2 respectively, indicating terrigenous organic matter deposited in an oxic condition.
The relationship of pristane and phytane with other $n$-alkanes can indicate the thermal maturity of the studied samples. A cross-plot of $\mathrm{Ph} / n-\mathrm{C} 18$ versus $\mathrm{Pr} / n-\mathrm{C} 17$ in Fig. 16 indicates that the coal samples from the terrace deposit and Miri formations are derived from terrigenous organic matter and these samples are thermally immature. The $\mathrm{R}_{22}$ index indicates the salinity of a depositional setting and it is defined through the formula $\left[2 \times \mathrm{C}_{22} /\left(\mathrm{C}_{21}+\mathrm{C}_{23}\right)\right]$ (ten Haven et al. 1988). All the analyzed samples display low $\mathrm{R}_{22}$ index values of less than 2 , with the highest value of 1.86 identified in sample BR2-3 of the Liang Formation. 


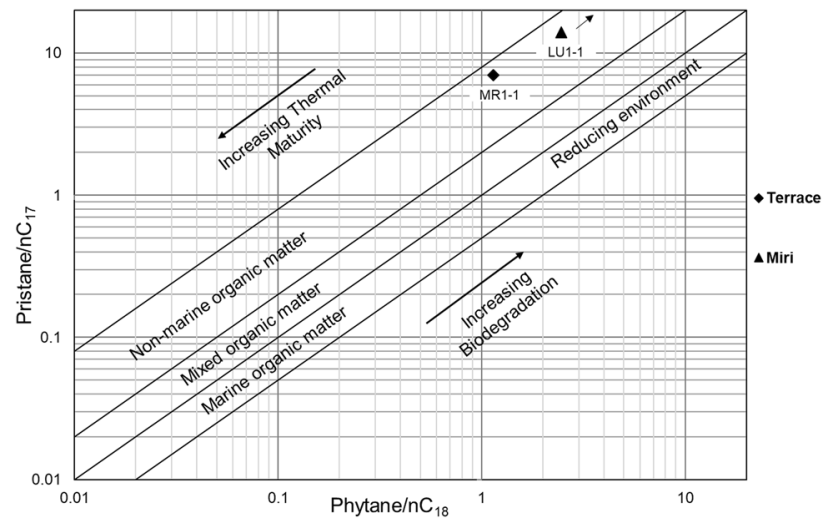

Fig. $16 \mathrm{~A}$ cross-plot of pristane $/ \mathrm{nC}_{17}$ versus phytane $/ \mathrm{nC}_{18}$ ratio of the terrace deposit and Miri coal samples (modified after Peters et al. 2005)

Use of $P_{\text {aq }}$ ratio can also contribute to palaeodepositional environment analysis as this index illustrates the hydrological regime of depositional site of the studied sample (Ficken et al. 2000). The $P_{\text {aq }}$ ratio is defined as $\left(\mathrm{nC}_{23}+\mathrm{nC}_{25}\right) /\left(\mathrm{nC}_{23}+\mathrm{nC}_{25}+\mathrm{nC}_{29}+\mathrm{nC}_{31}\right)$ and acts as a proxy for submerged/floating aquatic macrophyte versus terrestrial plant input to lake sediments that is retrieved from n-alkane information (Ficken et al. 2000). Terrestrial land input is indicated by low $P_{\text {aq }}$ values of less than 0.1 , whereas values ranging from 0.1 to 0.4 suggest emergent macrophytes. In this study, the $P_{\text {aq }}$ values for the samples contain values ranging from 0.14 to 0.39 , suggesting the presence of terrestrial, emergent plant input in the depositional site. This is parallel with primarily low vegetation index values (with the exception of BR2-1, BR2-3 and TL1-1 samples) calculated from maceral abundances as displayed in Fig. 15(b).
The Miocene-Quaternary formations as source rocks

\section{Hydrocarbon generation potential}

The generating potential of all selected samples from the studied formations are assessed through the relationship between $S_{2}$ and TOC (Fig. 17). The cross-plot exhibits the "excellent" generating potential for terrace coals, whereas the lignitic sand samples have "poor" potential of hydrocarbon generation. In the Liang Formation, the coal samples have a "good to excellent" generation potential and "poor" generation potential for the coaly shale as well as shale samples. An "excellent" generation potential is also observed in the Miri Formation coal samples and a "poor" generating potential is identified for the shale samples of the same formation. The Setap Shale Formation records no potential in hydrocarbon generating potential due to the low $\mathrm{S}_{2}$ and TOC values.

\section{Thermal maturity}

Vitrinite reflectance is a parameter that can be utilized to indicate the evaluation of source rock thermal maturity as a result of its sensitivity to temperature changes (Jumat et al. 2018; Osli et al. 2019). In this study, the ECE-UN (1998) classification utilizes vitrinite reflectance values of selected coal and coaly shale samples from studied formations in order to rank the samples. The classification in Fig. 6 shows that the samples have vitrinite reflectance readings that range from 0.30 to $0.46 \%$, giving a sub-bituminous to medium rank $\mathrm{D}$ for the samples.

Other maturity-related parameters to be applied in thermal maturity evaluation include $T_{\max }$ and PI. The distribution of thermal maturity for studied samples are illustrated in a cross-plot of HI versus $T_{\max }$ (Fig. 18), which shows that majority of the samples lies within the "immature" window. All samples belonging to the Setap Shale Formation,
Fig. 17 A cross-plot of PY versus TOC to illustrate the generation potential of the studied formations

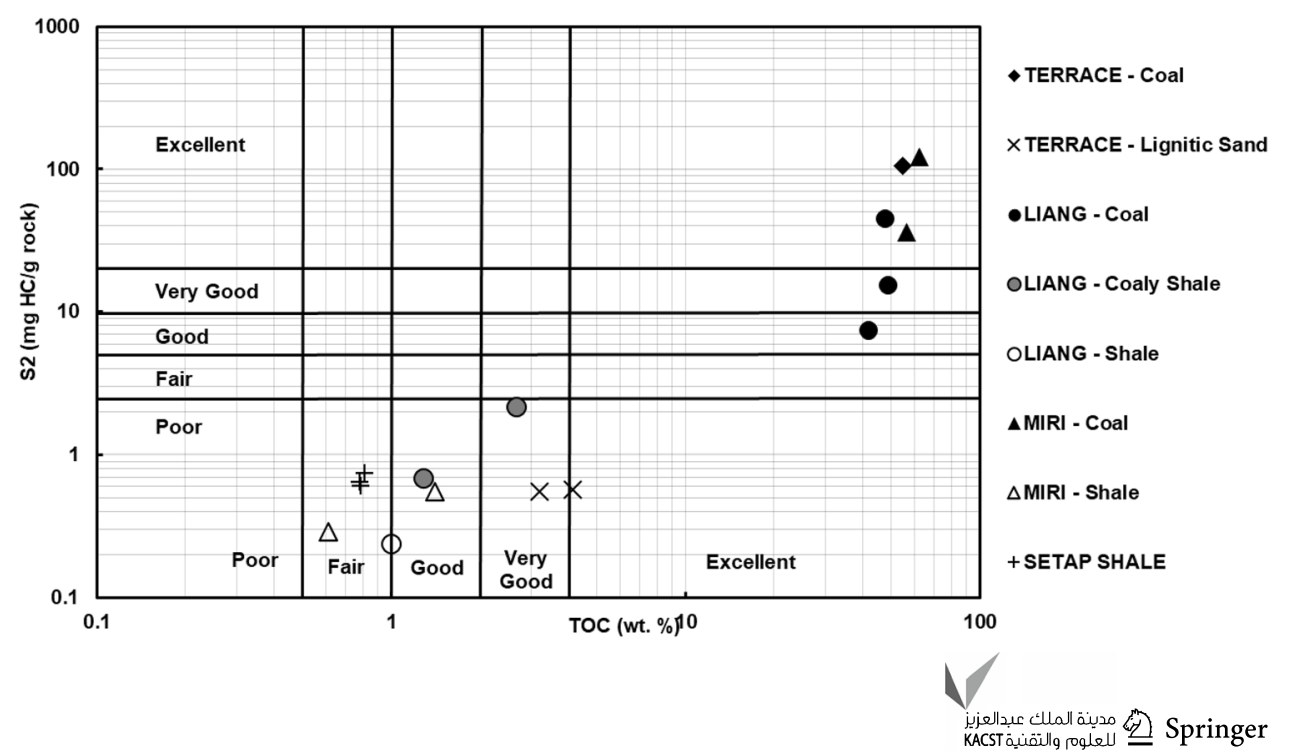




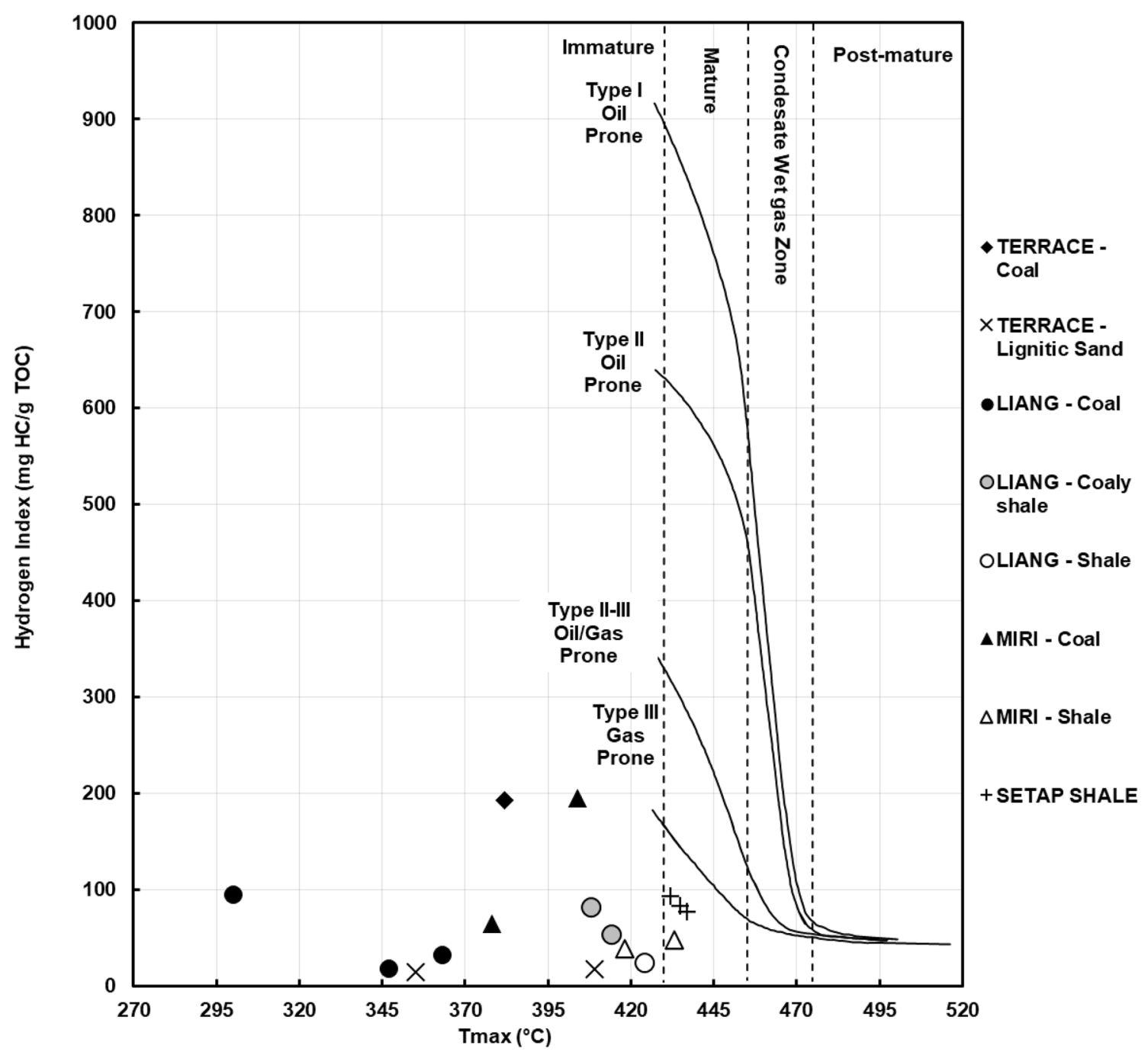

Fig. 18 A cross-plot of HI versus $T_{\max }$ to indicate the thermal maturity state of the studied formations

Fig. 19 A cross-plot of $T_{\max }$ versus $\% \mathrm{R}_{0}$ to show the thermal maturity of the studied formations

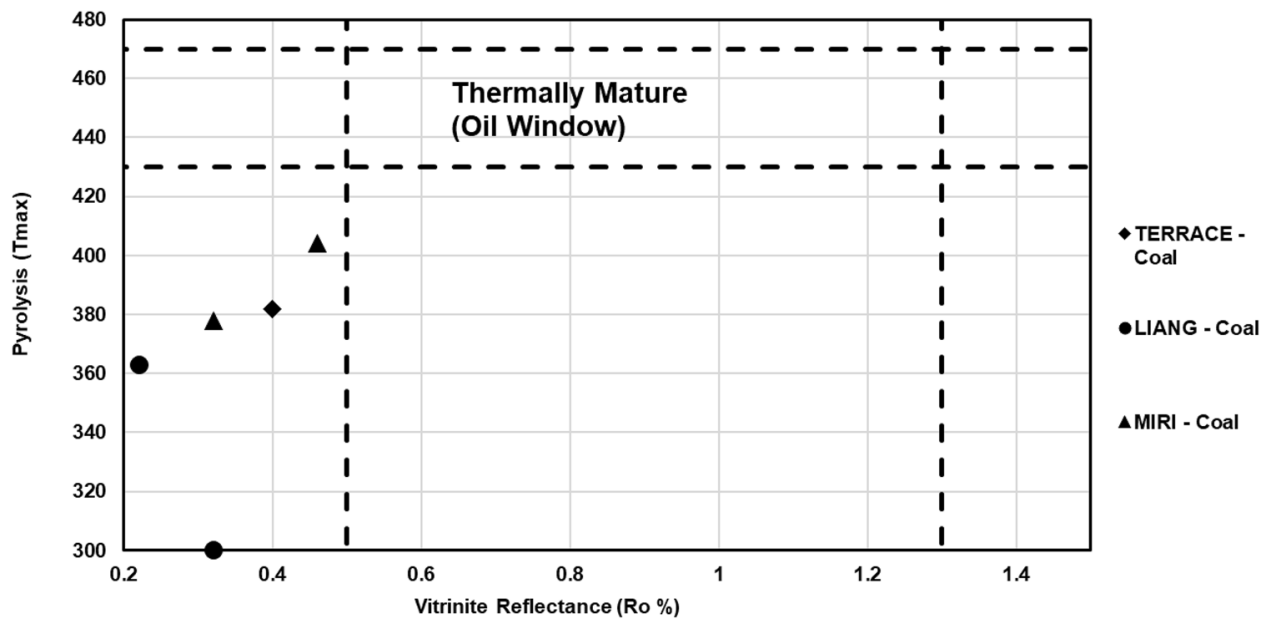


together with TN1-1 and KL1-1 of the Miri Formation, are within the thermally mature zone. Additionally, the low thermal maturity state of the terrace deposit, Liang and Miri coal samples are similarly identified in a cross-plot of $T_{\max }$ versus vitrinite reflectance in Fig. 19. The low thermal maturity state of the selected samples from the studied formations are also confirmed by the CPI values that are ranging from 2.11 to 3.77 .

\section{Conclusion}

This study investigated the geochemical characteristics and organic petrographical properties of the terrace deposits, Liang, Miri and Setap Shale formations. Abundance of macerals and Rock-Eval pyrolysis results indicate that the dominating kerogen types identified in the samples of these formations is kerogen type III (gas-prone) due to abundance of huminite. Minor kerogen type II-III (oil and gas prone) is also identified as a result of liptinite being the second most abundant maceral in the studied formations. Maceral analysis and geochemical characterization results conclude that the coal samples of the studied Formations are identified to be deposited in a mangrove setting that is exposed to marine influence. This is further supported by the bi-modal and normal distribution of $n$-alkanes in the studied samples. Although these outcrops samples are thermally immature, the best source rock generation potential among the four deposits belong to coals, whereas any non-coal layers are of fair to poor potential.

Acknowledgement The authors would like to thank Universiti Brunei Darussalam for providing the research Grant: UBD/OAVCRI/ CRGWG(007)/170401 which allows more geochemical studies of rock samples in Brunei. The authors would also like to express gratitude to Nurhazwana Jumat, Siti Lieyana Mohd Azffri and Nurzafirah Zainin for their contribution as well as assistance in fieldwork and sample collection.

Funding The funding for the analyses of this project is from the Universiti Brunei Darussalam grant numbered UBD/OAVCRI/ CRGWG(007)/170401.

Open Access This article is licensed under a Creative Commons Attribution 4.0 International License, which permits use, sharing, adaptation, distribution and reproduction in any medium or format, as long as you give appropriate credit to the original author(s) and the source, provide a link to the Creative Commons licence, and indicate if changes were made. The images or other third party material in this article are included in the article's Creative Commons licence, unless indicated otherwise in a credit line to the material. If material is not included in the article's Creative Commons licence and your intended use is not permitted by statutory regulation or exceeds the permitted use, you will need to obtain permission directly from the copyright holder. To view a copy of this licence, visit http://creativecommons.org/licenses/by/4.0/.

\section{References}

Abdullah WH (1999) Petrographic features of oil-prone coals from the Brunei-Muara District, Negara Brunei Darussalam. Proc Geol Soc Malays Bull 45:621-627

Abdullah WH (2003) Coaly source rocks of NW Borneo: role of suberinite and bituminite in oil generation and expulsion. Bull Geol Soc Malays 47(May):153-163

Abieda HS, Harith ZZT, Rahman AHA (2005) (2005) Depositional controls on petrophysical properties and reservoir characteristics of Middle Miocene Miri Formation sandstones. Sarawak Geol Soc Malays Bull 51:63-75

American Society for Testing and Materials (ASTM) D3174 (2004) "Standard Method for Ash in the Analysis Sample of Coal and Coke from Coal". In: annual book of ASTM standards, gaseous fuels coal and coke, 05. ASTM, Philadelphia, PA, 322-326

American Standard for Testing and Materials (ASTM) D7708 (2014) "Standard test method for microscopical determination of the reflectance of vitrinite dispersed in sedimentary rocks," 2014, 10p

Back S, Morley CK, Simmons MD, Lambiase JJ (2001) Depositional environment and sequence stratigraphy of Miocene deltaic cycles exposed along the Jerudong anticline, Brunei Darussalam. J Sediment Res 71(6):913-921

Back S, Strozyk F, Kukla PA, Lambiase JJ (2008) Three-dimensional restoration of original sedimentary geometries in deformed basin fill, onshore Brunei Darussalam, NW Borneo. Basin Res 20(1):99-117

Baillie P, Darman H, Fraser TH (2004) Deformation of Cenozoic Basins of Borneo and West Sulawesi. Proceedings, deepwater and frontier exploration in Asia \& Australasia symposium

Burgan AM, Ali CA (2010) An assessment of paleodepositional environment and maturity of organic matter in sediments of the Setap Shale and Belait formations in West Sabah, East Malaysia by organic geochemical methods. Chin J Geochem 29(1):42-52

Calder J, Gibling M, Mukhopadhyay P (1991) Peat formation in a westphalian B piedmont setting, cumberland basin, nova scotia. Bull Soc Geol Fr 162(2):283-298

Curiale J, Morelos J, Lambiase J, Mueller W (2000) Brunei darussalam characteristics of selected petroleums and source rocks. Org Geochem 31(12):1475-1493

Didyk BM, Simoneit BRT, Brassell ST, Eglinton G (1978) Organic geochemical indicators of palaeoenvironmental conditions of sedimentation. Nature 272(5650):216-222

Diessel CF (1992) Coal-bearing depositional systems. Springer-Verlag, Berlin

Economic Commission for Europe-United Nations (ECE-UN) (1998) International classification of in-seam coals, economic commission for Europe, committee on sustainable energy, United Nations, New York. Document ENERGY/1998/19, 41

Eglinton G, Hamilton RJ (1967) Leaf Epicuticular Waxes. Science 156(3780):1322-1335

Espitalié J, Deroo G, Marquis F (1985) Rock-Eval pyrolysis and its applications. Revue De L Institut Francais Du Petrole 40(5):563-579

Ficken KJ, Li B, Swain DL, Eglinton G (2000) An n-alkane proxy for the sedimentary input of submerged/floating freshwater aquatic macrophytes. Org Geochem 31(7-8):745-749

Hakimi MH, Abdullah WH, Sia SG, Makeen YM (2013) Organic geochemical and petrographic characteristics of Tertiary coals in the northwest Sarawak, Malaysia: implications for palaeoenvironmental conditions and hydrocarbon generation potential. Mar Pet Geol 48:31-46

Hall R (1996) Reconstructing cenozoic SE Asia. In: Hall R, Blundell DJ (eds) Tectonic evolution of SE Asia. Geological Society London Special Publication, London, pp 153-184

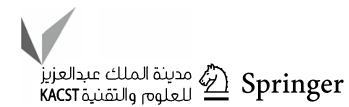


Hall R (1997) Cenozoic tectonics of SE Asia and Australasia. In: Howes JVC, Noble RA (eds) Petroleum systems of SE Asia and Australasia. Indonesian Petroleum Association, Jakarta, pp 47-62

Hall R, Nichols G (2002) Cenozoic sedimentation and tectonics in Borneo: climatic influences on orogenesis. Geol Soc London Spec Publ 191(1):5-22

Hutchison CS (1996) The 'Rajang accretionary prism' and 'Lupar Line' problem of Borneo. Geol Soc Lond Spec Publ 106(1):247-261

Hutchison CS (2005) Geology of North-West Borneo: sarawak. Elsevier, Brunei and Sabah

International Committee for Coal Petrology (ICCP) (1998) The new vitrinite classification (ICCP System 1994). Fuel 77:349-358

International Committee for Coal Petrology (ICCP) (2001) The new inertinite classification (ICCP System 1994). Fuel 80:459-471

International Standard Organisation (ISO 7404-2) (2009) Methods for the petrographic analysis of bituminous coal and anthracite-Part 2: method for preparing coal samples. International Organization for Standardization, Geneva, Switzerland, $\mathrm{p} 7$

International Standard Organisation (ISO 7404-3) (2009) Methods for the petrographic analysis of coals-Part 3: method of determining maceral group composition. International Organization for Standardization, Geneva, Switzerland, $\mathrm{p} 7$

James D (1984) The geology and the hydrocarbon potential of Negara Brunei Darussalam. Muzium Brunei Special Publication, Brunei, p 169

Jia TY, Rahman AH (2009) Comparative analysis of facies and reservoir characteristics of Miri Formation (Miri) and Nyalau formation (Bintulu), Sarawak. Bull Geol Soc Malays 55(2009):39-45

Jumat N, Shalaby MR, Eahsanul Haque ALM, Aminul Islam M, Hoon LL (2018) Geochemical characteristics, depositional environment and hydrocarbon generation modeling of the upper cretaceous Pakawau group in Taranaki Basin, New Zealand. J Petrol Sci Eng 163:320-339

Kalaitzidis S, Bouzinos A, Papazisimou S, Christanis K (2004) A shortterm establishment of forest fen habitat during Pliocene lignite formation in the Ptolemais Basin, NW Macedonia, Greece. Int J Coal Geol 57:243-263

Kalaitzidis S, Siavalas G, Skarpelis N, Araujo CV, Christanis K (2010) Late Cretaceous coal overlying karstic bauxite deposits in the ParnassusGhiona Unit, Central Greece: coal characteristics and depositional environment. Int J Coal Geol 81(4):211-226

Kessler FL, Jong J (2014) Habitat and C-14 ages of lignitic terrace deposits along the northern Sarawak Coastline. Bull Geol Soc Malays 60:27-34

Koopman A (1996) Regional geological setting. In: Sandal ST (ed) The geology and hydrocarbon resources of Negara Brunei Darussalam. Bandar Seri Begawan, Syabas, pp 49-63

Lambiase JJ, Rahim AAA, Peng CY (2002) Facies distribution and sedimentary processes on the modern Baram Delta: implications for the reservoir sandstones of NW Borneo. Mar Pet Geol 19(1):69-78

Lambiase JJ, Cullen AB (2013) Sediment supply systems of the Champion "Delta" of NW Borneo: implications for deepwater reservoir sandstones. J Asian Earth Sci 76:356-371

Langford FF, Blanc-Valleron MM (1990) Interpreting Rock-Eval pyrolysis data using graphs of pyrolizable hydrocarbons vs. total organic carbon (1). AAPG Bull 74(6):799-804

Levell BK (1987) The nature and significance of regional unconformities in the hydrocarbon-bearing Neogene sequences offshore West Sabah. Geol Soc Malays Bull 21:55-90

Moss SJ, Chambers J, Cloke I, Carter A, Satria D, Ali JR, Baker S (1997) New observations on the sedimentary and tectonic evolution of the Tertiary Kutai Basin, East Kalimantan. In: Fraser AJ, Matthews SJ, Murphy RW (eds) Petroleum geology of Southeast Asia. Geological Society London Special Publication, London, pp 395-416

Murtaza M, Rahman AHA, Sum CW, Konjing Z (2018) Facies associations, depositional environments and stratigraphic framework of the early Miocene-Pleistocene successions of the Mukah-Balingian Area, Sarawak, Malaysia. J Asian Earth Sci 152:23-38

Osli LN, Shalaby MR, Islam MA (2019) Hydrocarbon generation modeling and source rock characterization of the Cretaceous-Paleocene Taratu Formation, Great South Basin, New Zealand. J Pet Explor Prod Technol 9(1):125-139

Peters KE, Cassa MR (1994) Applied source-rock geochemistry. In: Magoon LB, Dow WG (eds) The petroleum system-From source to trap. American Association of Petroleum Geologists Memoir, Tulsa, pp 93-120

Peters K, Walters C, Moldowan J (2005) The biomarker guide: Biomarkers and isotopes in petroleum systems and Earth history. Cambridge University Press, New York

Peters KE, Walters CC, Moldowan JM (2007) The biomarker guide: biomarkers and isotopes in the environment and human history. Cambridge University Press, Cambridge

Peters KE, Walters CC, Moldowan JM (2007) The biomarker guide: biomarkers and isotopes in petroleum systems and earth history. Cambridge University Press, Cambridge

Petronas Research, Scientific Services, \& Petronas. Petroleum Management Unit (1999) The petroleum geology and resources of Malaysia: Kuala Lumpur, Malaysia, Petroliam Nasional Berhad, 665

Pickel W, Kus J, Flores D, Kalaitzidis S, Christanis K, Cardott BJ, Misz-Kennan M, Rodrigues S, Hentschel A, Hamor-Vido M, Crosdale P, ICCP (2017) Classification of liptinite-ICCP system 1994. Int J Coal Geol 169:40-61

Powell TG, McKirdy DM (1973) Relationship between Ratio of Pristane to Phytane, Crude Oil Composition and Geological Environment in Australia. Nat Phys Sci 243(124):37-39

Rahman AHA, Menier D, Mansor MY (2014) Sequence stratigraphic modelling and reservoir architecture of the shallow marine successions of Baram field, West Baram Delta, offshore Sarawak, East Malaysia. Mar Pet Geol 58:687-703

Rahman MNIA, Tahir SH (2018) Measured section for the possible stratotype of the miri formation, At Miri Hill, North Sarawak. Malays Geol Behav 2(2):10-16

Sandal S (1996) The geology and hydrocarbon resources of Negara Brunei Darussalam. Brunei Shell Petroleum Company Sendirian Berhad and Brunei Museum, Seria, p 243

Scherer M, Hitam R (1992) Distribution and maturation of source rocks in Brunei Darussalam. Am Assoc Pet Geol Bull 76:1125

Schreurs J (1997) The petroleum geology of Negara Brunei Darussalam: an update. Proceedings of an international conference on petroleum systems of SE Asia and Australasia

Shalaby MR, Osli LN, Kalaitzidis S, Islam MA (2019) Thermal maturity and depositional palaeoenvironments of the Cretaceous-Palaeocene source rock Taratu Formation, Great South Basin, New Zealand. J Petrol Sci Eng 181:106156

Siddiqui NA, EL-Ghali MA, Rahman AH, Mijinyawa A, Ben-Awuah J (2013) Depositional environment of shallow-marine sandstones from outcrop gamma-ray $\operatorname{logs}$, Belait Formation, Meragang Beach, Brunei Darussalam. Res J Environ Earth Sci 5(6):305-324

Siddiqui NA, Rahman AHA, Sum CW, Mathew MJ, Menier D (2014) Facies characteristics and static reservoir connectivity of some siliciclastic tertiary outcrop successions in Bintulu and Miri, Sarawak, East Malaysia. AAPG Search and Discovery, 51035

Sýkorová I, Pickel W, Christanis K, Wolf M, Taylor GH, Flores D (2005) Classification of huminite-ICCP System 1994. Int J Coal Geol 62(1-2):85-106

Tate RB (1971) Radiocarbon ages from Quaternary terraces-Prehistory in Brunei. Brunei Museum J 2(3):108-123

Tate RB (1974) Palaeo-environmental studies in Brunei. Brunei Museum J 3:285-305

Ten Haven HL, De Leeuw JW, Damsté JS, Schenck PA, Palmer SE, Zumberge JE (1988) Application of biological markers in the 
recognition of palaeohypersaline environments. Geol Soc London Spec Publ 40(1):123-130

Tingay MRP, Hillis RR, Morley CK, Swarbrick RE, Okpere EC (2003) Variation in vertical stress in the Baram Basin, Brunei: tectonic and geomechanical implications. Mar Pet Geol 20(10):1201-1212

Tingay MR, Hillis RR, Morley CK, King RC, Swarbrick RE, Damit AR (2009) Present-day stress and neotectonics of Brunei: implications for petroleum exploration and production. AAPG Bull 93(1):75-100

Tissot BP, Welte DH (1984) Petroleum formation and occurrence: a new approach to oil and gas exploration. Springer-Verlag, Berlin, p 538
Torres J, Gartrell A, Hoggmascal N (2011) Redefining a sequence stratigraphic framework for the miocene to present in Brunei Darussalam: roles of local tectonics, eustacy and sediment supply. International Petroleum Technology Conference, 15-17

Wilford GE (1961) The geology and mineral resources of Brunei and adjacent parts of sarawak: with descriptions of seria and miri oilfields. British Borneo Geological Survey, Memoirs 10, Brunei Darussalam: Brunei Press Limited

Publisher's Note Springer Nature remains neutral with regard to jurisdictional claims in published maps and institutional affiliations. 